\title{
Article \\ Potassium Application Positively Modulates Physiological Responses of Cocoa Seedlings to Drought Stress
}

\author{
Esther Anokye *, Samuel T. Lowor (D), Jerome A. Dogbatse and Francis K. Padi \\ Cocoa Research Institute of Ghana, P. O. Box 8, New Tafo-Akim, Ghana; slowor2@yahoo.co.uk (S.T.L.); \\ agbesi2000@yahoo.com (J.A.D.); padifrancis@yahoo.co.uk (F.K.P.) \\ * Correspondence: esticals@yahoo.com
}

check for updates

Citation: Anokye, E.; Lowor, S.T.; Dogbatse, J.A.; Padi, F.K. Potassium Application Positively Modulates Physiological Responses of Cocoa Seedlings to Drought Stress.

Agronomy 2021, 11, 563. https:// doi.org/10.3390/agronomy11030563

Academic Editor: Andrew Daymond

Received: 14 February 2021

Accepted: 3 March 2021

Published: 17 March 2021

Publisher's Note: MDPI stays neutral with regard to jurisdictional claims in published maps and institutional affiliations.

Copyright: (c) 2021 by the authors. Licensee MDPI, Basel, Switzerland. This article is an open access article distributed under the terms and conditions of the Creative Commons Attribution (CC BY) license (https:/ / creativecommons.org/licenses/by/ $4.0 /)$.

\begin{abstract}
With increasing frequency and intensity of dry spells in the cocoa production zones of West Africa, strategies for mitigating impact of water stress on cocoa seedling survival are urgently required. We investigated the effects of applied potassium on biomass accumulation, physiological processes and survival of cocoa varieties subjected to water stress in pot experiments in a gauzehouse facility. Four levels of potassium $(0,1,2$, or $3 \mathrm{~g}$ / plant as muriate of potash) were used. Soil water stress reduced plant biomass accumulation (shoot and roots), relative water content (RWC), chlorophyll content and fluorescence. Leaf phenol and proline contents were increased under water stress. Additionally, compared to the well-watered conditions, soils under water stress treatments had higher contents of exchangeable potassium and available phosphorus at the end of the experimental period. Potassium applied under well-watered conditions reduced leaf chlorophyll content and fluorescence and increased leaf electrolyte leakage, but improved the growth and integrity of physiological functions under soil water stress. Potassium addition increased biomass partitioning to roots, improved RWC and leaf membrane stability, and significantly improved cocoa seedling survival under water stress. Under water stress, the variety with the highest seedling mortality accumulated the highest contents of phenol and proline. A significant effect of variety on plant physiological functions was observed. Generally, varieties with PA 7 parentage had higher biomass partitioning to roots and better seedling survival under soil moisture stress. Proportion of biomass partitioned to roots, RWC, chlorophyll fluorescence and leaf electrolyte leakage appear to be the most reliable indicators of cocoa seedling tolerance to drought.
\end{abstract}

Keywords: allometry; chlorophyll fluorescence; electrolyte leakage; relative water content

\section{Introduction}

Within the cocoa (Theobroma cacao L.) belt in West Africa where the bulk of the crop is produced globally, the annual three to five months of dry weather (spanning November to April) result in soil water deficits that reduce cocoa seedling survival particularly during the first 24 months after planting. At the turn of the decade, projected decline in rainfall in the semi-deciduous forest zone and high rainfall forest zone of Ghana indicated declines of $2 \%$ and $3.1 \%$, respectively by 2020 [1]. Over the past decade, the Ghana Cocoa Board's seedling supply targets were consistently above 20 million per year, with the last five years supply exceeding 45 million seedlings annually. Actual proportion of seedling mortalities in farmers' plots due to drought is mainly anecdotal, but matching of the national seedling supply numbers to the annual cocoa expansion area suggests that not more than $30 \%$ actually survive the dry spells. The projection of the effects of climate change scenarios suggests that climate change will continue to have a negative impact on cocoa seedling establishment, as historical data show a progressive rise in temperature and decrease in rainfall in all the six agro-ecological zones of Ghana [2].

Cocoa, having evolved in the Amazon basin with high rainfall and humidity levels, short periods of drought in the production regions impact severely on the crop's physiological functions and yield [3,4]. Key physiological processes of the crop that leads to 
flushes of leaf and shoot growth, rhythms of root initiation and expansion, and periodicity of flowering are all influenced by the patterns of rainfall [5]. In addition to the effects of increasing dry spells on cocoa production in West Africa [6], high intensity of land-use have led to loss of carbon, reducing soil water holding capacities and further exacerbating the effects of limited water availability on production $[7,8]$. The approaches adopted to reduce the effects of drought on cocoa growth and yield include planting under various shade regimes [9], application of various types of mulch [10] and the selection of varieties with better seedling survival following post-rainy seasons in field evaluations [11,12]. These approaches have had varying levels of success under farmers' production conditions [13], and an integrated approach may be required to reduce cocoa seedling losses in the field.

Increased concentrations of micronutrients and macronutrients have been implicated in enhancing plant adaptation to moisture stress [14]. For example, under water stress, plants given higher doses of phosphorus showed an increase in photosynthetic efficiency compared with those given lower doses [15]. Potassium is known to be involved in stomatal opening, osmoregulation, cell expansion and increase in dry matter production [16,17]. Drought stress limits both root growth and the rates of potassium diffusion in the soil towards the roots, thereby limiting potassium acquisition [14]. The reduced potassium availability within the rooting zone further reduces the plant resistance to drought stress, as well as potassium absorption [18]. Cakmak [14] observed that potassium application can minimize the production of reactive oxygen species (ROS). Under drought stress, photosynthesis is limited by impairment in stomata regulation, conversion of light energy into chemical energy and phloem export of photosynthates from source leaves into sink organs. As the impairment in photosynthetic carbon dioxide fixation occurs, molecular oxygen is activated, leading to oxidative degradation of chlorophyll and membranes [19]. Under adequate potassium nutrition, there is inhibition of the transfer of photosynthetic electrons to molecular oxygen, thus reducing ROS production [14]. In plants supplied with adequate amounts of soil potassium, leaf water relations were influenced such that turgor potential, as a function of relative water content, is increased and such plants are generally found to have better hydrated tissues than potassium-stressed plants [20]. De La Guardia and Benlloch [21] observed that accumulation of potassium in the cell favors water uptake, thus generating the necessary cell turgor required for growth. Under field conditions, Blanchet et al., [22] found that high additions of $\mathrm{K}$ increased yield and water use efficiency of Italian ryegrass. In olive trees, potassium starvation depressed stomatal conductance and transpiration as well as inhibiting shoot growth [23].

In the present study, we explored the impact of applied potassium on growth and physiological functions of a diverse set of cocoa varieties under moisture stress. Our objectives were, first, to examine whether increasing soil potassium content can mitigate the effects of water stress on cocoa seedling survival; and secondly, to determine whether significant varietal effects exist in cocoa for survival under soil water stress.

\section{Materials and Methods}

\subsection{Plant Materials and Growth Conditions}

Clones belonging to different genetic groups were used to generate thirteen varieties for the study (Table 1). Two experiments were conducted in the gauzehouse of the Cocoa Research Institute of Ghana, (CRIG). Four cocoa varieties were used in the first experiment, whereas 10 varieties were used in the second experiment, with one variety T85/799 $\times$ PA 7 common to both experiments. Seed pods were generated by manual pollination and seedlings were raised in $7 \mathrm{~kg}$ of soil (Table 2) in $25 \times 30 \mathrm{~cm}$ polyethylene bags for three months before the imposition of potassium and moisture treatment. The soil used was sandy loam taken from a heavily cropped land of cocoa for 30 years, typical of cocoa soils under rehabilitation. Table 2 indicates the chemical composition of the soil. Soils were thoroughly mixed before measuring into the nursery bags to ensure that at the start of each experiment, all seedlings were under the same soil conditions. In the first experiment, seedlings were nursed on 20 February 2015 and water stress treatment imposed between 
July and August 2015. The relative humidity (\%) during the stress imposition period varied from $84 \pm 0.6$ ( $9 \mathrm{~h} \mathrm{GMT}$ ) to $69 \pm 1.0$ (15 h GMT). Average day maximum and night minimum temperatures $\left({ }^{\circ} \mathrm{C}\right)$ were $29.4 \pm 0.18$ and $18.8 \pm 0.10$, respectively. Seedlings used in the second experiment were nursed on 24 August 2015, and the period of water stress imposition occurred in January to February 2016. The relative humidity varied from $69 \pm 2.2$ (9 h GMT) to $40 \pm 2.1$ ( $15 \mathrm{~h}$ GMT). Average day maximum and night minimum temperatures $\left({ }^{\circ} \mathrm{C}\right)$ were $35.6 \pm 0.19$ and $17.2 \pm 0.37$, respectively.

Table 1. Description of varieties used by pedigree or origin.

\begin{tabular}{|c|c|c|}
\hline Variety & Use in this Trial & Source/Parentage \\
\hline T63/967 × SCA 9 & Experiment 1 & $\begin{array}{l}\text { T63/967 was derived from a Nanay } \times \text { Iquitos cross collected by Posnette } \\
\text { from Trinidad in } 1944 * \text { SCA } 9 \text { is a clone of Upper Amazon (Scavina) origin }\end{array}$ \\
\hline T63/971 × SCA 9 & Experiment 1 & $\begin{array}{l}\text { T63/971 was derived from a Nanay } \times \text { Iquitos cross collected by Posnette } \\
\text { from Trinidad in } 1944 .\end{array}$ \\
\hline PA $7 \times$ MAN 15-2 & Experiment 1 & $\begin{array}{l}\text { PA } 7 \text { is a clone of Parinari origin, belonging to the Marañón genetic group. } \\
\text { Man 15-2 is a clone selection from an international clone trial } \ddagger \text {. Mainly of } \\
\text { Purús and Amelonado origin } \dagger\end{array}$ \\
\hline $\mathrm{T} 85 / 799 \times$ PA 7 & Experiments $1 \& 2$ & $\begin{array}{c}\text { T85/799 was derived from a Nanay } \times \text { Iquitos }(\text { NA } 34 \times \text { IMC 60) cross } \\
\text { collected by Posnette from Trinidad in } 1944 .\end{array}$ \\
\hline NA33 × CRG 9006 & Experiment 2 & $\begin{array}{l}\text { NA } 33 \text { is a clone introduction from the Nanay genetic group. CRG } 9006 \text { is } \\
\text { clone selection made in Ghana from GU } 144 / \mathrm{C} \times \text { EQX 3338. GU } 144 / \mathrm{C} \text { is a } \\
\text { clone of Guiana origin }\end{array}$ \\
\hline PA $7 \times$ CRG 8914 & Experiment 2 & $\begin{array}{l}\text { PA } 7 \text { belongs to the Marañón genetic group. CRG } 8914 \text { is a clone selection } \\
\text { from a cross made in Ghana from T85/799 } \times \text { CAS } 3 \text {. CAS } 3 \text { is an } \\
\text { Amelonado clone }\end{array}$ \\
\hline PA $7 \times$ EQX 3338 & Experiment 2 & $\begin{array}{l}\text { EQX } 3338 \text { is a clone introduction originating from Ecuador. Belongs to the } \\
\text { Trinitario genetic group }+\end{array}$ \\
\hline PA150 × CRG 8914 & Experiment 2 & $\begin{array}{l}\text { PA } 150 \text { belongs to the Marañón genetic group. CRG } 8914 \text { was derived from } \\
\qquad 85 / 799 \times \text { CAS } 3 .\end{array}$ \\
\hline PA $7 \times$ PA 118 & Experiment 2 & Both PA 7 and PA 118 belong to the Marañón genetic group. \\
\hline T60/887 × CRG 8914 & Experiment 2 & $\begin{array}{l}\text { T60/887 was derived from Marañón } \times \text { Nanay }(\text { PA } 7 \times \text { NA 32) cross made in } \\
\text { Trinidad and collected by Posnette in } 1944 \text {. Predominantly a Nanay }+\end{array}$ \\
\hline T63/967 × EQX 3338 & Experiment 2 & $\begin{array}{l}\text { T63/967 was derived from a Nanay } \times \text { Iquitos cross. EQX } 3338 \text { is a } \\
\text { Trinitario clone }\end{array}$ \\
\hline T63/967 × PA 118 & Experiment 2 & $\begin{array}{l}\text { T63/967 was derived from a Nanay } \times \text { Iquitos cross. PA } 118 \text { belongs to the } \\
\text { Marañón genetic group. }\end{array}$ \\
\hline T63/967 × PA 88 & Experiment 2 & $\begin{array}{l}\text { T63/967 was derived from a Nanay } \times \text { Iquitos cross. PA } 88 \text { belongs to the } \\
\text { Marañón genetic group. }\end{array}$ \\
\hline
\end{tabular}

Table 2. Effect of water stress treatments on chemical properties of a sandy loam soil used to evaluate 10 cocoa varieties in a gauzehouse facility for six months.

\begin{tabular}{ccccc}
\hline Soil Property & Initial Contents & \multicolumn{3}{c}{ Final Contents } \\
\cline { 3 - 5 } & & Water Stress & Well-Watered & $P$ \\
\hline Organic C $(\%)$ & $1.160 \pm 0.04$ & $1.262 \pm 0.030$ & $1.237 \pm 0.034$ & 0.415 \\
pH & $5.90 \pm 0.03$ & $6.14 \pm 0.027$ & $6.13 \pm 0.03$ & 0.817 \\
Total N (\%) & $0.105 \pm 0.004$ & $0.109 \pm 0.002$ & $0.107 \pm 0.002$ & 0.499 \\
Available P $(\mathrm{mg} / \mathrm{kg})$ & $49.46 \pm 4.00$ & $35.46 \pm 1.38$ & $30.94 \pm 1.65$ & 0.030 \\
Exchangeable K $(\mathrm{cmol} / \mathrm{kg})$ & $0.67 \pm 0.020$ & $1.164 \pm 0.042$ & $1.041 \pm 0.033$ & $<0.001$ \\
Ca $(\mathrm{cmol} / \mathrm{kg})$ & $4.72 \pm 0.18$ & $4.99 \pm 0.11$ & $5.12 \pm 0.11$ & 0.085 \\
$\mathrm{Mg}(\mathrm{cmol} / \mathrm{kg})$ & $2.18 \pm 0.11$ & $1.74 \pm 0.066$ & $1.73 \pm 0.074$ & 0.779 \\
\hline
\end{tabular}




\subsection{Experimental Design and Treatments}

The nursery bags were arranged on raised gauzehouse benches. Each of the two experiments was divided into two sub-sets of experiments and were run concurrently. For a particular experiment, each set was conducted in a Completely Randomized Design (CRD) with three replications and two factors. Ten cocoa seedlings were used per treatment for each of the three replications in each set of the experiment. The factors were variety (four varieties in the first experiment and 10 varieties in the second) and potassium at four levels.

\subsubsection{Potassium Treatments}

The potassium treatments were applied as dry granules of muriate of potash (MOP, $60 \% \mathrm{~K}_{2} \mathrm{O}$ ) at four levels of $0 \mathrm{~g}, 1 \mathrm{~g}, 2 \mathrm{~g}$, and $3 \mathrm{~g} /$ plant in $7 \mathrm{~kg}$ of soil to three-month old cocoa seedlings in the nursery bags, approximately $2 \mathrm{~cm}$ below soil surface. No other nutrient was applied.

\subsubsection{Water Stress Treatments}

One month after potassium application, the experimental set-up was divided into two sets, and either watered to field capacity ( $50 \%$ water holding capacity) three times a week or water was withheld until 55 days in the first experiment, and 45 days in the second experiment. The period of water stress imposition in both experiments was based on when the seedlings died, after which data recording was no longer possible. Each of the two experiments (with four or ten varieties) therefore had a well-watered and a water-stress treatment and four levels of applied $\mathrm{K}$.

\subsection{Data Collection}

The soils used in the experiments were analyzed for important plant nutrients before and at the end of the experiments (Table 2). Organic carbon was determined using the wet combustion method [27]. Soil pH was determined in a 1:2.5 ( $w / v)$ soil:water suspension [28]. The soil suspension (well mixed ten grams of air-dried soil and twenty five milliliters of deionized water) was allowed to stand for $10 \mathrm{~min}$ and soil $\mathrm{pH}$ was determined using Mettler Toledo pH meter; Total nitrogen in soil was determined using the Kjeldahl method [29], which involved sample digestion, distillation, and titration. Percent total nitrogen in the soil was calculated using the formula:

$$
\text { Total Nitrogen }(\%)=(T \times N \times 1.401) / W
$$

where: $T=$ Titre value of soil sample $(\mathrm{mLs}), N=$ Normality of titrant concentration, $W=$ Weight of soil sample (g) and $1.401=$ Constant factor. Available phosphorus was determined using the Troug method [30]. For this, five grams of soil was weighed into shaker bottles and $100 \mathrm{mLs}$ of $0.2 \mathrm{~N} \mathrm{H}_{2} \mathrm{SO}_{4}$ was added to the soil and shaken for $2 \mathrm{~h}$ on a mechanical shaker at room temperature. The extracts were filtered through Whatman No. 42 filter papers into $100 \mathrm{mLs}$ volumetric flasks and analyzed for phosphorus by colorimetry with UV Visible Cecil Spectrophotometer (CE 7400 model). Exchangeable basic cations (K, $\mathrm{Ca}$ and $\mathrm{Mg}$ ) were extracted with $1 \mathrm{M}$ neutral ammonium acetate solution and filtrate was analyzed by the atomic absorption spectrophotometer [31].

Volumetric soil water content (VSWC) was monitored on a weekly basis for the various treatments using the soil moisture meter SM200 (Delta T devices Ltd., Cambridge, UK). Measurement of VSWC for each of the treatments started after six days of water stress. In all, five time point measurements were made within the period of the experiment (corresponding to 130 days from planting the varieties). Volumetric soil water contents were determined before each watering event under well-watered treatments. Stem diameter ( $5 \mathrm{~cm}$ above the soil) was measured using a vernier caliper at monthly intervals from three months after transplanting till the end of the experiment. Using CL-01 Chlorophyll Content Meter (Hansatech Instruments Ltd., King's Lynn, UK), the leaf chlorophyll content 
of the fifth and sixth leaves (counting from the youngest fully expanded leaf) per plant was determined. The photosystem II quantum yield $\left(\mathrm{F}_{\mathrm{V}} / \mathrm{F}_{\mathrm{M}}\right)$ was measured using Leaf Chlorophyll Fluorescence Meter (FP100; Photon Systems Instruments, Drasov, Czech Republic) on leaves that had been dark-adapted for $30 \mathrm{~min}$ before measurement. For both leaf chlorophyll content and fluorescence, measurements were performed between 7 and $10 \mathrm{~h}$ GMT.

Relative water content (RWC) was determined using ten leaf discs excised from the mid-section from each of three leaves using a $1.5 \mathrm{~cm}$ diameter cork borer following the method of Yamasaki and Dillenburg [32]. The fresh weight (FW), turgid weight (TW) and dry weight (DW) of the leaves were determined and RWC (\%) was calculated as [(FW $\mathrm{DW}) /(\mathrm{TW}-\mathrm{DW})] \times 100$; total phenol content in leaves was determined by the FolinCiocalteau method, described in Ragazzi and Veronese [33]. Essentially, $0.2 \mathrm{~g}$ of defatted sample was weighed into a $50 \mathrm{~mL}$ falcon tube, $30 \mathrm{~mL}$ of Methanol: $\mathrm{HCl}$ mixture solution was added to the sample in the container and place on a shaker to shake for two (2) hours at maximum speed. After two hours the filtrate was decanted into another container. Filtrate of $1 \mathrm{~mL}$ was placed into a test tube and $5 \mathrm{~mL}$ of 1:9 mL of Follin Ciocalteu's Phenol reagent was added. After $8 \mathrm{~min}, 4 \mathrm{~mL}$ of $0.075 \mathrm{~g} / \mathrm{mL}$ of $\mathrm{Na}_{2} \mathrm{CO}_{3}$ solution was added to the mixture in the tube. The solution turned blue and the contents were left to stand for $1 \mathrm{~h}$ at $30^{\circ} \mathrm{C}$ and $1 \mathrm{~h}$ at $0{ }^{\circ} \mathrm{C}$ after which the color or absorbance was read at $760 \mathrm{~nm}$ using the UV/Vis spectrophotometer. Free proline was determined as described by Bates et al. [34]. Plant leaves of $0.5 \mathrm{~g}$ were homogenized in $10 \mathrm{~mL}$ of $3 \%$ aqueous sulfosalicylic acid and filtered with wathman filter paper No. 2 (centrifuge at 13,000 rpm for $10 \mathrm{~min}$ ). Filtrate of $2 \mathrm{~mL}$ with $2 \mathrm{~mL}$ acid ninhydrin and $2 \mathrm{~mL}$ glacial acetic acid were placed in the test tube for $1 \mathrm{~h}$ at $100{ }^{\circ} \mathrm{C}$, after which the reaction mixture was placed in an ice bath for the reaction to be terminated and extracted with $4 \mathrm{~mL}$ of Toluene in a test tube using a stirrer for 15-20 s. The colored part containing toluene was separated from the aqueous phase, warmed to room temperature and absorbance read at $520 \mathrm{~nm}$ on the spectrophotometer. Toluene was used as sample blank and the proline concentration was subjected to the formula. Leaf cell membrane stability was assessed through electrolyte leakage of leaf cell content as described by Lutts et al., [35] using 10 leaf discs of $1.5 \mathrm{~cm}$ diameter per treatment. Leaf segments were placed in stoppered vials containing $10 \mathrm{~mL}$ of deionized water and incubated at $25^{\circ} \mathrm{C}$ on a rotary shaker $(100 \mathrm{rpm})$. Electrical conductivity of the bathing solution (L1) was determined after $24 \mathrm{~h}$. Samples were then autoclaved at $120^{\circ} \mathrm{C}$ for $20 \mathrm{~min}$ and a last conductivity reading $(L 0)$ was obtained upon equilibration at $25^{\circ} \mathrm{C}$. The electrolyte leakage was defined as $L 1 / L 0$ and expressed as percent. The number of seedlings that survived the period of water stress imposition was assessed at weekly intervals. The plants were destructively sampled at the end of the experiment and data were taken on dry weights of shoots and roots.

\subsection{Statistical Analyses}

Except for the data on mortality of seedlings under water stress, the various data taken were subjected to analysis of variance (ANOVA) using GenStat Statistical software 9th edition. Separately for each watering regime in each of the two experiments, a factorial analyses of variety and $\mathrm{K}$ levels was carried out following the model of a completely randomized design and significant differences among the means at $p<0.05$ were compared using the standard error of difference. For the seedling mortality data, survival curves of cocoa seedlings were estimated using the Kaplan-Meier method [36]. Survival time was calculated as the number of weeks between the last watering event and the date when it was recorded as dead. Seedlings still alive at the end of the recording period were coded as right-censored. For each curve, a chi-square value was computed, comparing the observed and expected number of deaths, the sum of all chi-squared values and overall chi-square, from which a probability value was determined. 


\section{Results}

\subsection{Effects of Variety and Water Stress Treatments on Contents of Soil Nutrients and Water}

Following six months of cocoa seedling growth, soils under water stress had a higher nutrient content than soils under well-watered conditions (Table 2). Of the seven soil chemical properties assessed, soil moisture stress significantly affected only available $\mathrm{P}$ and exchangeable $\mathrm{K}$ (Table 2). For the amount of $\mathrm{K}$ remaining at the end of the experiment, there was no significant interaction between varieties and potassium levels. However, the main effect of $\mathrm{K}$ was significant. As depicted in Figure 1a, where K was not applied, no differences existed in residual soil $\mathrm{K}$ levels between water-stressed and well-watered conditions. At the other levels of applied $\mathrm{K}$, however, higher levels of exchangeable $\mathrm{K}$ accumulated in the stressed soils compared with well-watered soils used to grow the cocoa varieties. Consistent with the observations for $\mathrm{K}$, higher soil-available $\mathrm{P}$ was also maintained under water-stressed treatment (Figure 1b). Content of soil-available P was not affected by the $\mathrm{K}$ treatments (Table 2).

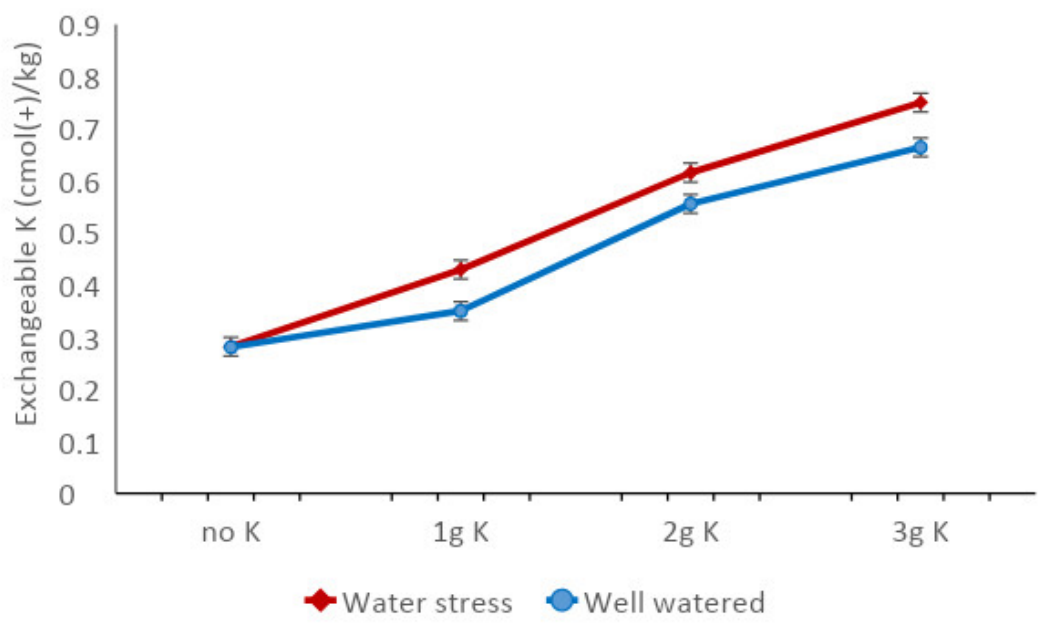

(a)

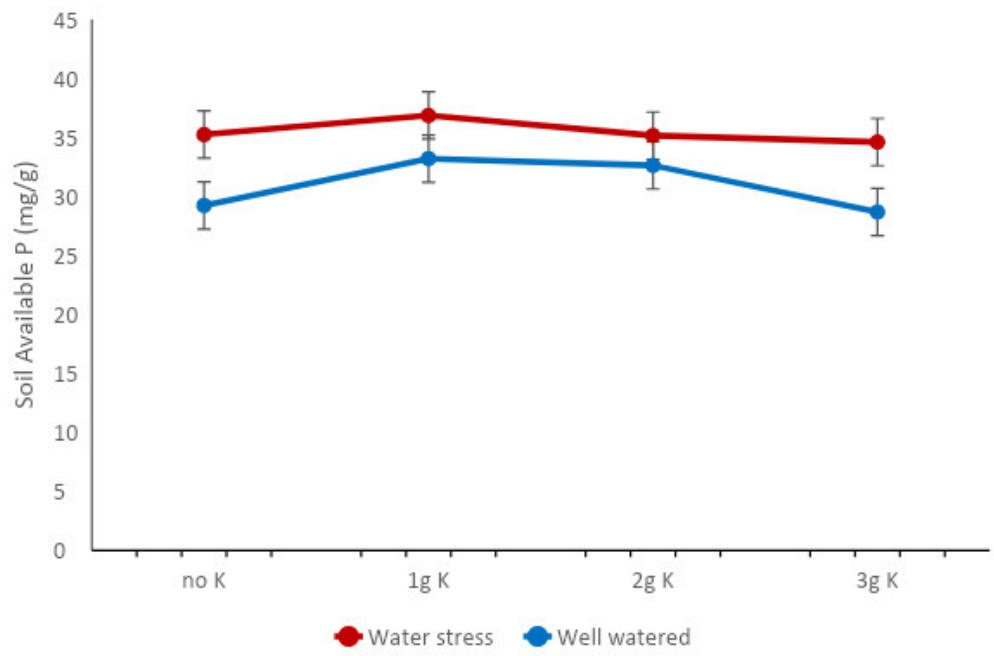

(b)

Figure 1. Soil contents of (a) exchangeable $K$, and (b) available P in well-watered and drought soils amended with various levels of potassium, after 55 days of irrigation treatment of cocoa seedlings grown in a gauzehouse facility. Bars represent the SED value to compare K levels at each water stress or well-watered treatment. 
Potassium application did not have any effect on volumetric soil water content under either well-watered or water-stressed conditions. Even under well-watered conditions, soil moisture content before each watering event on the sampling days reduced with the age of the seedlings, indicating increasing extraction of soil water with increase in plant size. Under well-watered conditions, soil water content taken before each watering event was significantly different between the varieties on all sampling dates. The two varieties with SCA 9 in their parentage extracted more water compared with the two with PA 7 parentage (Figure 2a). The pattern of soil water depletion was similar under water-stress conditions, except that significant differences were limited to sampling up to 20 days after cessation of watering (Figure $2 b$ ).

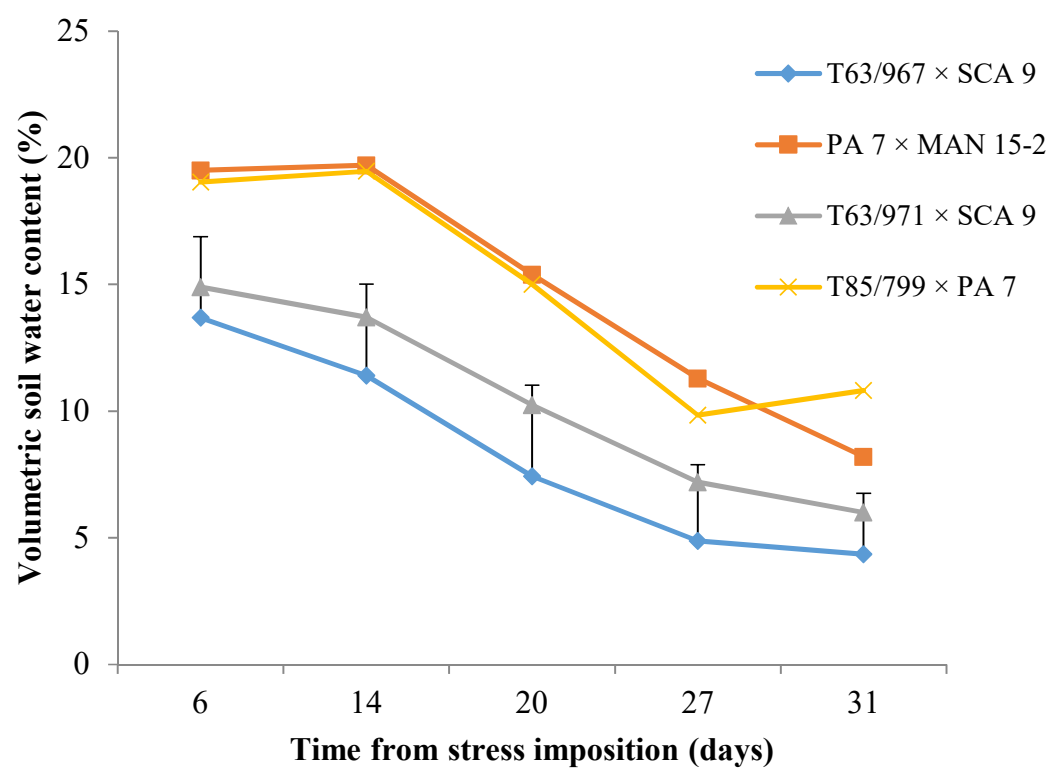

(a)

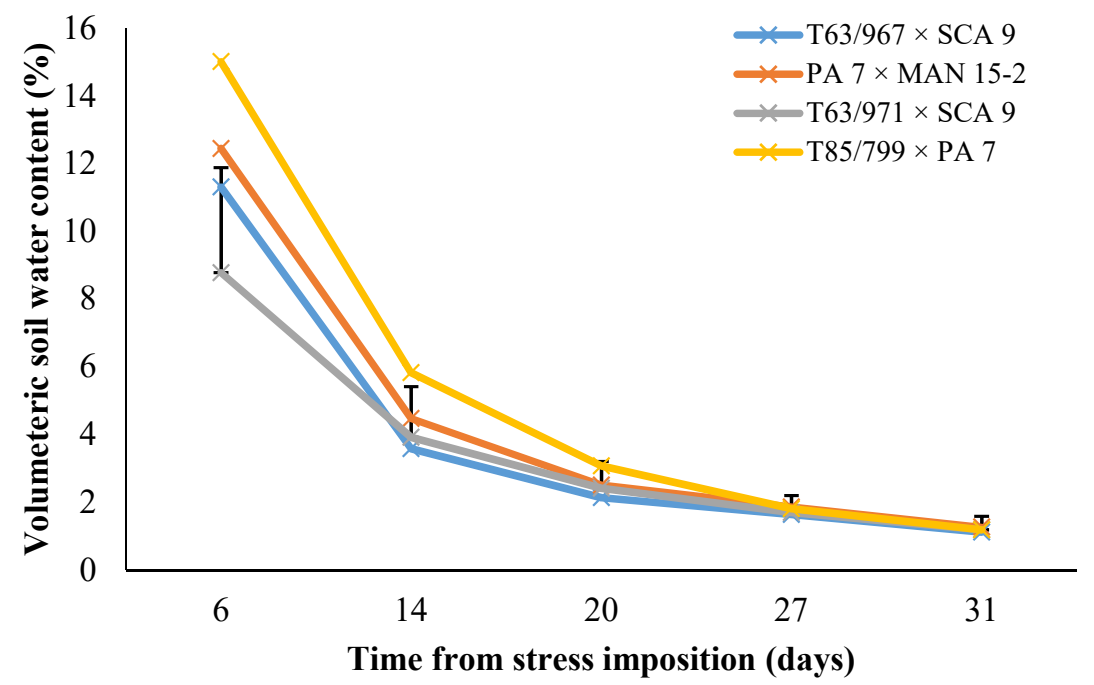

(b)

Figure 2. Changes in volumetric soil water contents under four cocoa varieties in (a) well-watered and (b) water-stressed treatments in a gauzehouse facility. In well-watered treatments, measurements were done prior to watering plants to field capacity. Bars represent the LSD value for comparing varieties at each sampling date 


\subsection{Effects of Water Stress and Potassium Application on Allometric Relationships of Cocoa Seedlings}

Significant effects of variety and $\mathrm{K}$ were observed for the dry weights of roots, stem, and leaves, length of tap roots and stem diameter in both experiments (Tables 3 and 4 ). The interactions between variety $\times \mathrm{K}$ for these traits were not significant in either experiment. The main effects are therefore reported.

Table 3. Allometric relationships of four cocoa seedling varieties as influenced by watering regime and potassium treatments, 55 days after water stress imposition in experiment 1 .

\begin{tabular}{|c|c|c|c|c|c|c|c|c|c|c|}
\hline \multirow{2}{*}{$\begin{array}{c}\text { Muriate of } \\
\text { Potassium (g/plant) }\end{array}$} & \multicolumn{2}{|c|}{$\begin{array}{l}\text { Stem Diameter } \\
(\mathrm{mm})\end{array}$} & \multicolumn{2}{|c|}{$\begin{array}{l}\text { Length of Tap Root } \\
(\mathrm{cm})\end{array}$} & \multicolumn{2}{|c|}{$\begin{array}{c}\text { Dry Weight of Roots } \\
\text { (g) }\end{array}$} & \multicolumn{2}{|c|}{$\begin{array}{c}\text { Dry Weight of Stem } \\
\text { (g) }\end{array}$} & \multicolumn{2}{|c|}{$\begin{array}{c}\text { Dry Weight of Leaves } \\
\text { (g) }\end{array}$} \\
\hline & Watered & Stressed & Watered & Stressed & Watered & Stressed & Watered & Stressed & Watered & Stressed \\
\hline 0 & 8.1 & 6.9 & 44.9 & 29.9 & 6.9 & 2.9 & 7.3 & 5.2 & 12.5 & 8.5 \\
\hline 1 & 8.4 & 7.5 & 33.7 & 30.8 & 5.8 & 3.1 & 8.1 & 5.3 & 12.6 & 8.9 \\
\hline 2 & 8.1 & 7.4 & 40.9 & 32.1 & 4.7 & 3.6 & 7.5 & 5.6 & 12.9 & 9.0 \\
\hline 3 & 9.0 & 8.5 & 36.4 & 34.5 & 5.9 & 4.4 & 8.3 & 6.4 & 13.1 & 9.0 \\
\hline $\begin{array}{l}\mathrm{SED}_{\mathrm{df}=32} \\
\text { Varieties }\end{array}$ & 0.29 & 0.23 & 4.21 & 2.33 & 0.62 & 0.22 & 0.71 & 0.38 & 0.86 & 0.67 \\
\hline T63/967 × SCA 9 & 9.1 & 7.8 & 44.9 & 37.3 & 6.9 & 3.6 & 10.1 & 6.4 & 15.4 & 9.5 \\
\hline $\mathrm{T} 63 / 971 \times$ SCA 9 & 8.0 & 7.2 & 40.9 & 29.6 & 4.7 & 2.8 & 7.3 & 5.3 & 12.7 & 9.1 \\
\hline PA $7 \times$ MAN 15-2 & 8.6 & 7.7 & 33.7 & 31.7 & 5.8 & 4.0 & 7.2 & 5.7 & 12.0 & 9.2 \\
\hline $\mathrm{T} 85 / 799 \times \mathrm{PA} 7$ & 8.0 & 7.6 & 36.4 & 28.7 & 5.9 & 3.8 & 6.4 & 5.1 & 11.0 & 7.5 \\
\hline $\mathrm{SED}_{\mathrm{df}=32}$ & 0.29 & 0.23 & 4.21 & 2.33 & 0.62 & 0.22 & 0.71 & 0.38 & 0.86 & 0.67 \\
\hline
\end{tabular}

Table 4. Allometric relationships of ten cocoa seedling varieties as influenced by watering regime and potassium treatments 45 days after water stress imposition in experiment 2 .

\begin{tabular}{|c|c|c|c|c|c|c|c|c|c|c|}
\hline \multirow{2}{*}{$\begin{array}{l}\text { Muriate of } \\
\text { Potassium } \\
\text { (g/plant) }\end{array}$} & \multicolumn{2}{|c|}{$\begin{array}{l}\text { Stem Diameter } \\
(\mathrm{mm})\end{array}$} & \multicolumn{2}{|c|}{$\begin{array}{l}\text { Length of Tap Root } \\
\text { (cm) }\end{array}$} & \multicolumn{2}{|c|}{$\begin{array}{l}\text { Dry Weight of Roots } \\
\text { (g) }\end{array}$} & \multicolumn{2}{|c|}{$\begin{array}{c}\text { Dry Weight of Stem } \\
\text { (g) }\end{array}$} & \multicolumn{2}{|c|}{$\begin{array}{l}\text { Dry Weight of Leaves } \\
\text { (g) }\end{array}$} \\
\hline & Watered & Stressed & Watered & Stressed & Watered & Stressed & Watered & Stressed & Watered & Stressed \\
\hline 0 & 7.9 & 6.7 & 34.4 & 25.2 & 5.6 & 1.8 & 8.5 & 3.4 & 14.7 & 8.6 \\
\hline 1 & 8.3 & 6.7 & 34.3 & 26.5 & 5.5 & 1.9 & 8.7 & 3.7 & 15.9 & 9.0 \\
\hline 2 & 8.1 & 6.9 & 31.5 & 30.3 & 5.0 & 2.1 & 8.6 & 3.7 & 15.8 & 8.9 \\
\hline 3 & 8.4 & 7.1 & 30.1 & 31.6 & 5.1 & 2.2 & 8.7 & 3.8 & 16.5 & 9.5 \\
\hline $\begin{array}{l}\mathrm{SED}_{\mathrm{df}=78} \\
\text { Varieties }\end{array}$ & 0.14 & 0.15 & 2.85 & 2.08 & 0.33 & 0.15 & 0.51 & 0.18 & 0.50 & 0.34 \\
\hline NA33 × CRG 9006 & 9.2 & 7.7 & 35.0 & 29.1 & 4.8 & 2.1 & 7.5 & 4.1 & 14.5 & 9.8 \\
\hline PA 7 × CRG 8914 & 8.9 & 8.0 & 37.1 & 32.1 & 4.8 & 2.2 & 7.2 & 4.0 & 16.5 & 10.5 \\
\hline $\begin{array}{c}\text { T63/967 × EQX } \\
3338\end{array}$ & 8.0 & 6.4 & 29.3 & 25.1 & 4.4 & 2.0 & 7.2 & 3.1 & 12.8 & 8.1 \\
\hline T85/799 × PA 7 & 8.0 & 7.0 & 33.4 & 28.9 & 6.2 & 2.3 & 9.0 & 4.1 & 16.6 & 9.0 \\
\hline PA150 × CRG 8914 & 8.6 & 7.0 & 33.8 & 25.6 & 6.8 & 1.9 & 11.1 & 4.2 & 18.3 & 10.3 \\
\hline PA 7 × EQX 3338 & 7.9 & 6.9 & 35.6 & 31.1 & 4.6 & 2.5 & 7.0 & 3.4 & 15.4 & 7.9 \\
\hline T63/967 × PA 118 & 7.1 & 6.1 & 29.6 & 26.6 & 5.8 & 1.5 & 9.3 & 3.0 & 15.5 & 7.4 \\
\hline PA7 $\times$ PA 118 & 7.5 & 6.3 & 38.1 & 33.7 & 4.3 & 1.7 & 7.0 & 2.9 & 14.9 & 7.8 \\
\hline $\begin{array}{c}\mathrm{T} 60 / 887 \times \mathrm{CRG} \\
8914\end{array}$ & 8.5 & 7.0 & 26.4 & 26.1 & 5.5 & 1.8 & 9.2 & 3.9 & 17.3 & 9.7 \\
\hline T63/967 × PA 88 & 8.1 & 6.3 & 28.2 & 25.5 & 5.7 & 2.0 & 11.8 & 3.8 & 15.4 & 9.6 \\
\hline $\mathrm{SED}_{\mathrm{df}=78}$ & 0.28 & 0.25 & 4.51 & 3.28 & 0.51 & 0.24 & 0.79 & 0.28 & 0.80 & 0.54 \\
\hline
\end{tabular}

Stem diameter increased with increasing amount of $\mathrm{K}$ applied, under well-watered and water-stressed conditions in both experiments. The effects of varieties on stem diameter increment was also significant under both well-watered and water stress conditions in the two experiments (Tables 3 and 4). Varieties with PA 7 in their parentage had less reduction in stem diameter under water stress relative to those without PA 7 in their parentage in both experiment 1 (Figure 3) and experiment 2 (Figure 4). 


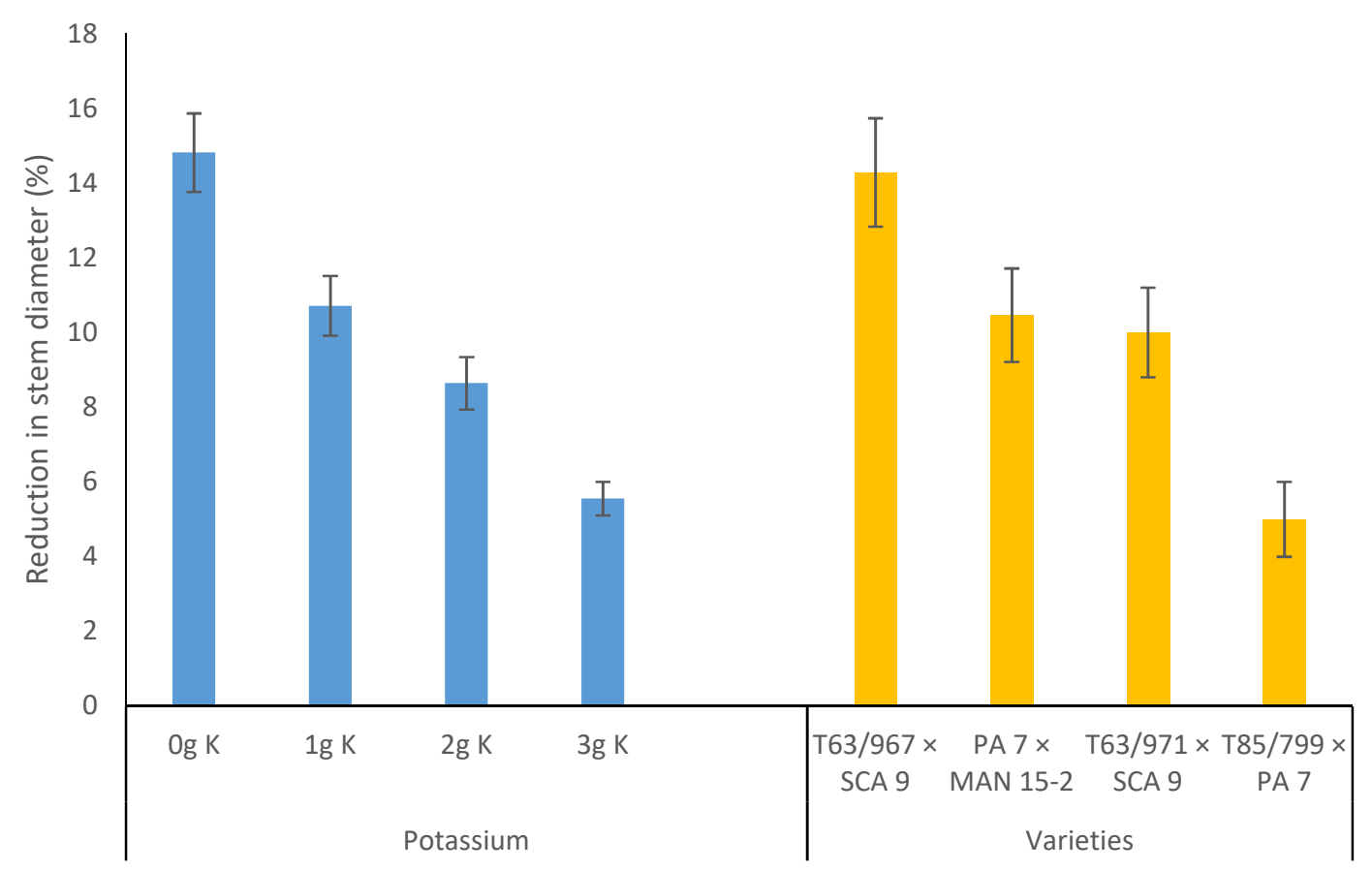

Figure 3. Reduction in stem diameter of cocoa seedlings under water-stress relative to well-watered conditions as affected by potassium application and varieties, 45 days from stress imposition. Bars represent standard error of the mean.

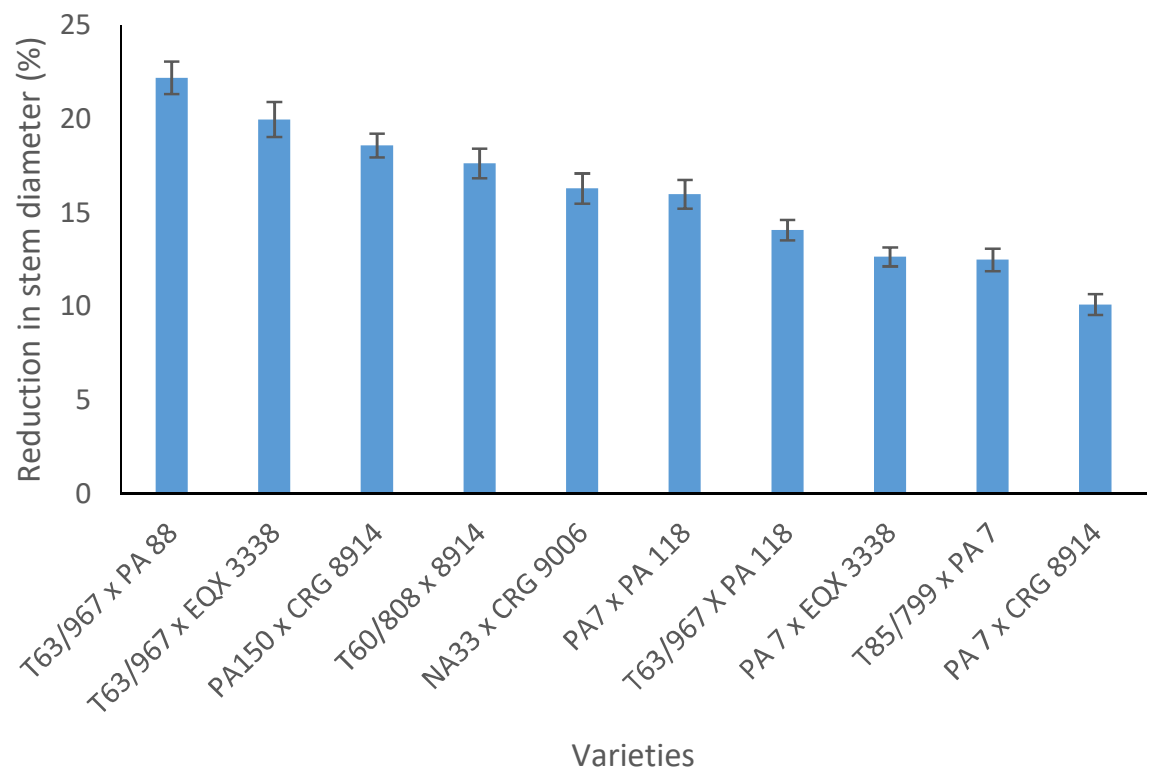

Figure 4. Reduction in stem diameter of cocoa varieties under water-stress relative to well-watered conditions 40 days from stress imposition. Bars represent standard error of the mean.

Water stress reduced biomass accumulation in both shoot and roots (Figure 5). The effects of water stress was, however, more severe on root biomass than shoot biomass. As indicated in Figure 6, root biomass reduced from 18\% of total biomass under well-watered conditions to $14 \%$ under water stress. Under well-watered conditions in experiment $1, \mathrm{~K}$ application significantly reduced the length of tap root and root biomass (Table 3). While similar observations were made in experiment 2, the length of tap root and root biomass were markedly reduced at $\mathrm{K}$ levels of $2 \mathrm{~kg}$ and $3 \mathrm{~kg}$ respectively (Table 4 ). Although no significant differences could be detected, a marginal increase in tap root length and dry root biomass could be detected as K levels increased under water stress (Tables 3 and 4). In- 
crease in dry weight of the above ground parts following $\mathrm{K}$ application under well-watered conditions was significant only for the dry weight of leaves in experiment 2 (Table 4). In the first experiment, T63/967 $\times$ SCA 9 had the longest tap root and root biomass under well-watered conditions. However, due to their higher sensitivity to water stress, the two varieties with SCA 9 in their parentage $($ T63/967 $\times$ SCA 9 and T63/971 $\times$ SCA 9) recorded lower root biomass but not length of tap root compared with the two PA 7-derived varieties (Table 3). For stem and leaf biomass, T63/967 $\times$ SCA 9 maintained the highest biomass under both well-watered and water stress conditions. In the second experiment, root biomass under well-watered conditions was highest in PA $150 \times$ CRG 8914. Under water stress, however, the top three varieties for root biomass had PA7 in their parentage, comprising PA $7 \times$ EQX 3338, T85/799 $\times$ PA 7 and PA $7 \times$ CRG 8914 (Table 4). For the aboveground parts (stem and leaf biomass) no consistent association between pedigree of varieties and biomass accumulation was clearly evident. PA $150 \times$ CRG 8914 and PA $7 \times$ CRG 8914 performed generally well under water stress for the aboveground parts, compared with other varieties.

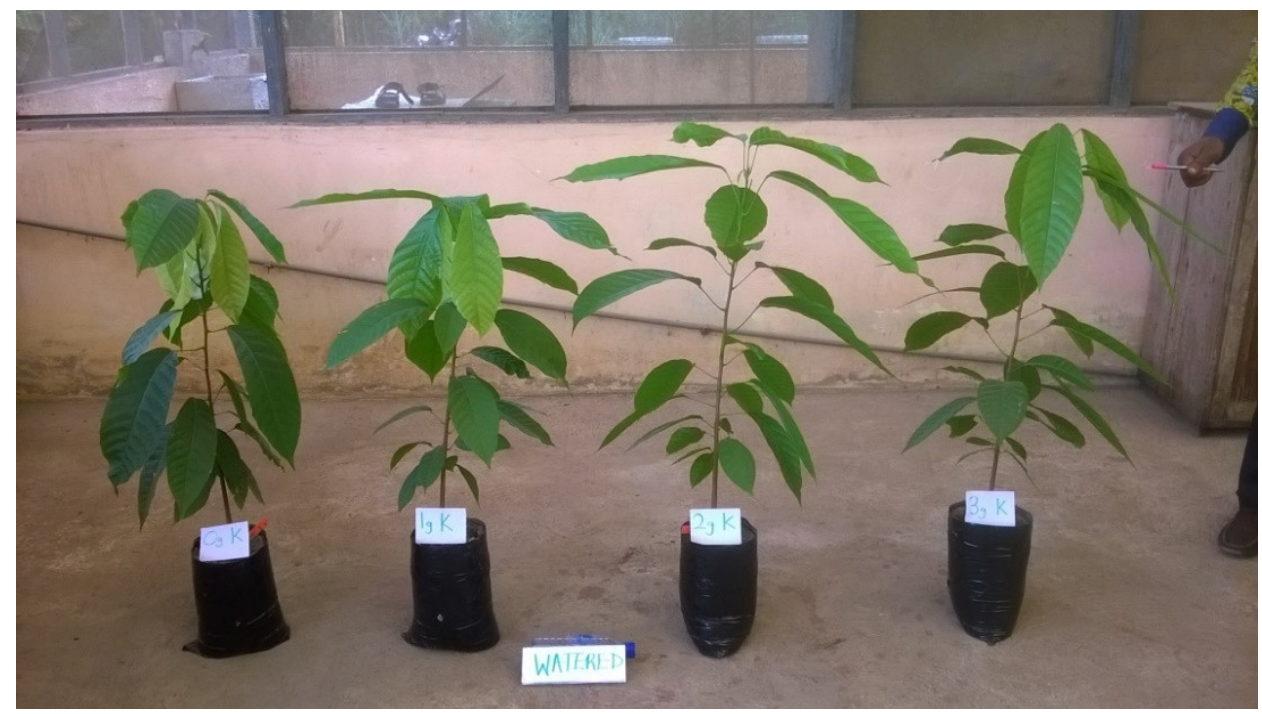

(a)

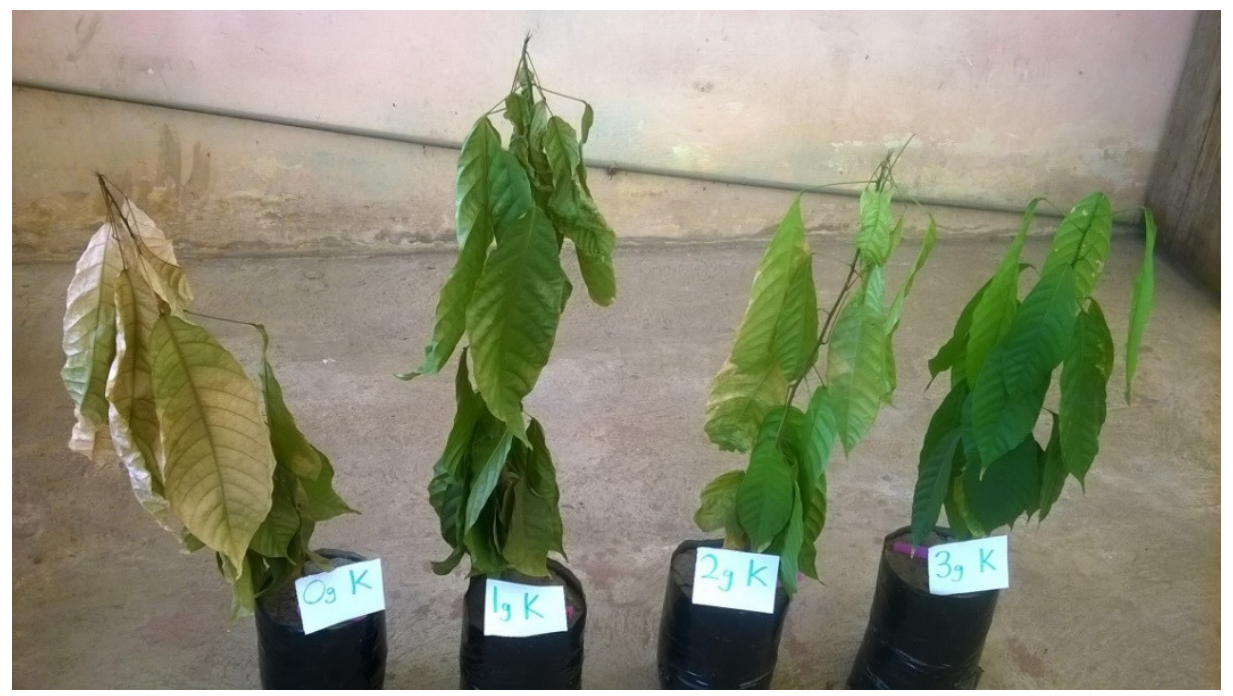

(b)

Figure 5. Effect of K on cocoa seedlings under (a) well-watered conditions and (b) water stress condition. 


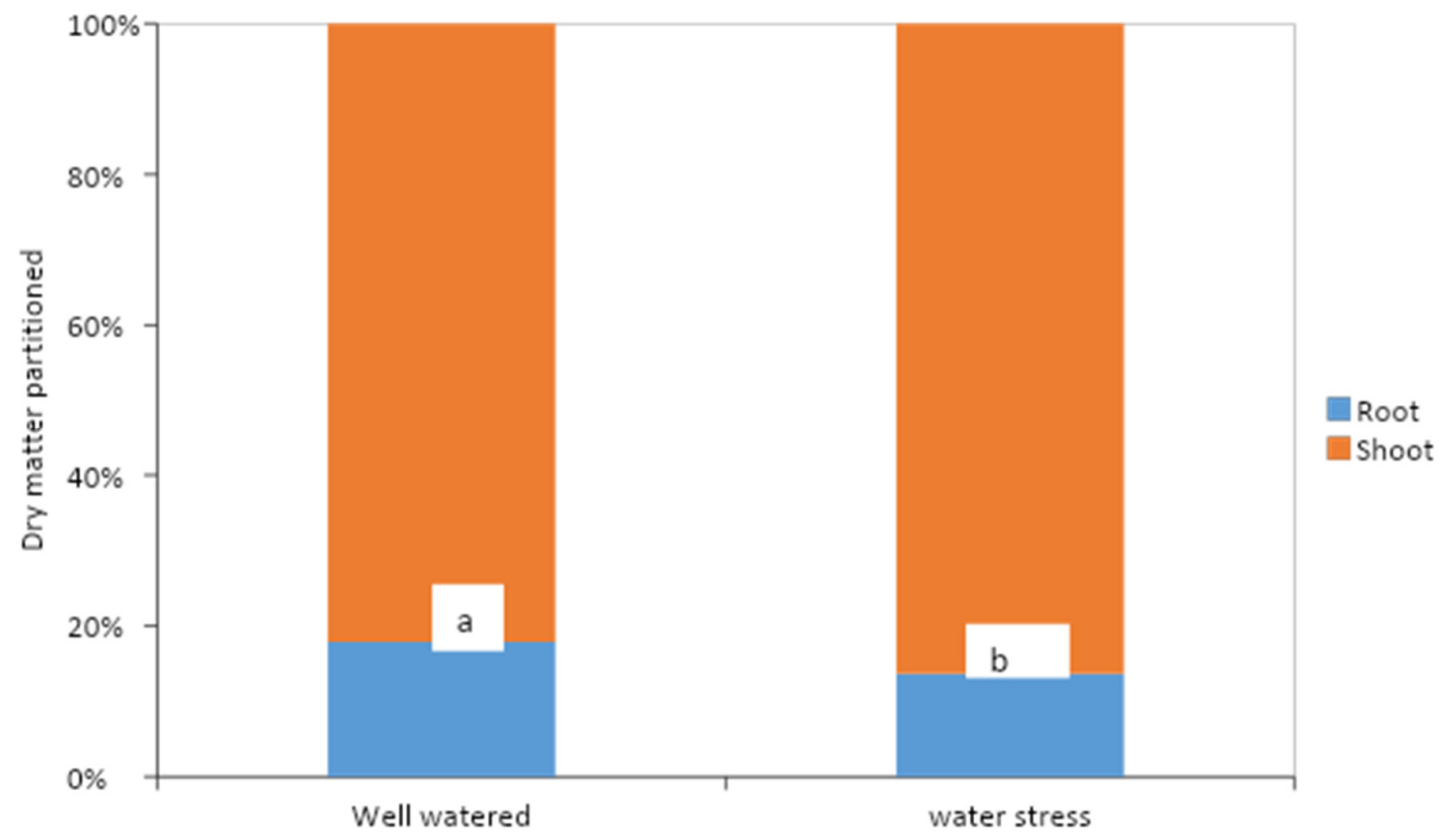

Figure 6. Relative dry matter partitioned into roots and shoots of cocoa seedlings after subjecting four month old cocoa seedlings to 55 days of water stress or well-watered conditions in a gauzehouse facility. Data from experiment 1 ; different letters ( $\mathrm{a}$ and $\mathrm{b}$ ) indicate significant differences at $p=0.05$.

\subsection{Effects of Potassium and Watering Regime on the Physiological Functions of Cocoa Varieties}

Water stress significantly reduced leaf chlorophyll content, chlorophyll fluorescence, RWC and leaf membrane stability (measured as electrolyte leakage), while increasing contents of leaf phenol and proline (Table 5).

Table 5. Leaf chlorophyll content and fluorescence, and leaf contents of total phenol and proline of cocoa seedlings as influenced by watering regime and potassium application in experiment 1 .

\begin{tabular}{ccccccccc}
\hline \multirow{2}{*}{$\begin{array}{c}\text { Muriate of Potash } \\
\text { (g/plant) }\end{array}$} & \multicolumn{2}{c}{$\begin{array}{c}\text { Leaf Chlorophyll } \\
\text { Content }\left(\mathbf{m m o l} / \mathbf{c m}^{\mathbf{2}}\right)\end{array}$} & \multicolumn{2}{c}{$\begin{array}{c}\text { Leaf Chlorophyll } \\
\text { Fluorescence } \mathbf{( F v / F m )}\end{array}$} & \multicolumn{2}{c}{$\begin{array}{c}\text { Leaf Phenol Content } \\
(\mathbf{m g} / \mathbf{g})\end{array}$} & $\begin{array}{c}\text { Leaf Proline Content } \\
(\boldsymbol{\mu g} / \mathbf{g})\end{array}$ \\
\cline { 2 - 9 } & Watered & Stressed & Watered & Stressed & Watered & Stressed & Watered & Stressed \\
\hline 0 & 11.1 & 5.2 & 0.67 & 0.15 & 10.1 & 16.8 & 9.9 & 1373.4 \\
1 & 10.5 & 4.9 & 0.65 & 0.30 & 11.1 & 19.5 & 13.1 & 1397.4 \\
2 & 9.4 & 4.2 & 0.63 & 0.19 & 11.8 & 19.6 & 13.2 & 1202.9 \\
3 & 10.1 & 4.3 & 0.61 & 0.29 & 11.8 & 20.7 & 12.9 & 1317.5 \\
SED $_{\mathrm{df}=32}$ & 0.87 & 0.72 & 0.02 & 0.07 & 0.11 & 0.22 & 0.71 & 9.92 \\
\hline
\end{tabular}

Though K application appears to reduce leaf chlorophyll content irrespective of the watering regime, the effect was not significant (Table 5). Under the well-watered condition, application of $\mathrm{K}$ significantly reduced chlorophyll fluorescence, unlike the water stress condition where chlorophyll fluorescence was significantly improved. Leaf phenol content increased with higher $\mathrm{K}$ application levels irrespective of the watering regime. The results suggest that proline levels increased with higher $\mathrm{K}$ application rates under well-watered conditions but without any consistent pattern observed under water stress conditions (Table 5). Interestingly, proline levels quantified under water stress conditions were significantly higher compared to well-watered conditions and regardless of the K application rates. RWC and the proportion of dry matter partitioned to roots were unaffected by K application under well-watered conditions, but increasing $\mathrm{K}$ application rate increased both RWC and the proportion of root biomass under water stress (Figure 7). K application increased electrolyte leakage from leaf membrane under well-watered conditions; under 
water stress, however, K application significantly reduced leaf electrolyte leakage (Figure 8). Irrespective of the watering regime, the optimal rate was $1 \mathrm{~g}$ MOP per plant as increasing rates resulted in reduced leaf membrane stability.

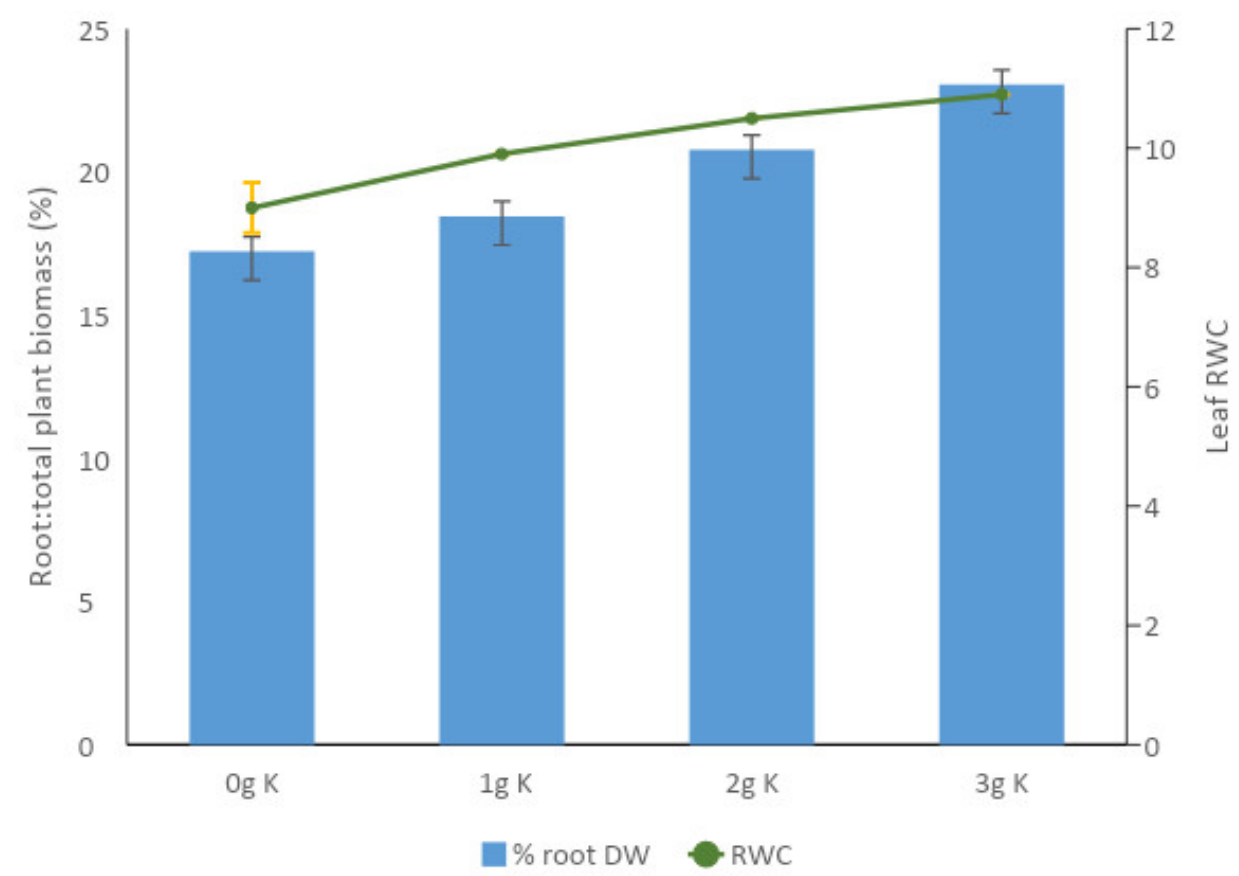

Figure 7. Effect of potassium on the proportion of dry matter partitioned to roots and leaf relative water content (RWC) of cocoa seedlings evaluated under water stress conditions in a gauzehouse facility. RWC was determined at 35 days after water stress, root dry weight at 55 days after stress. Values represent data from experiment 1 .

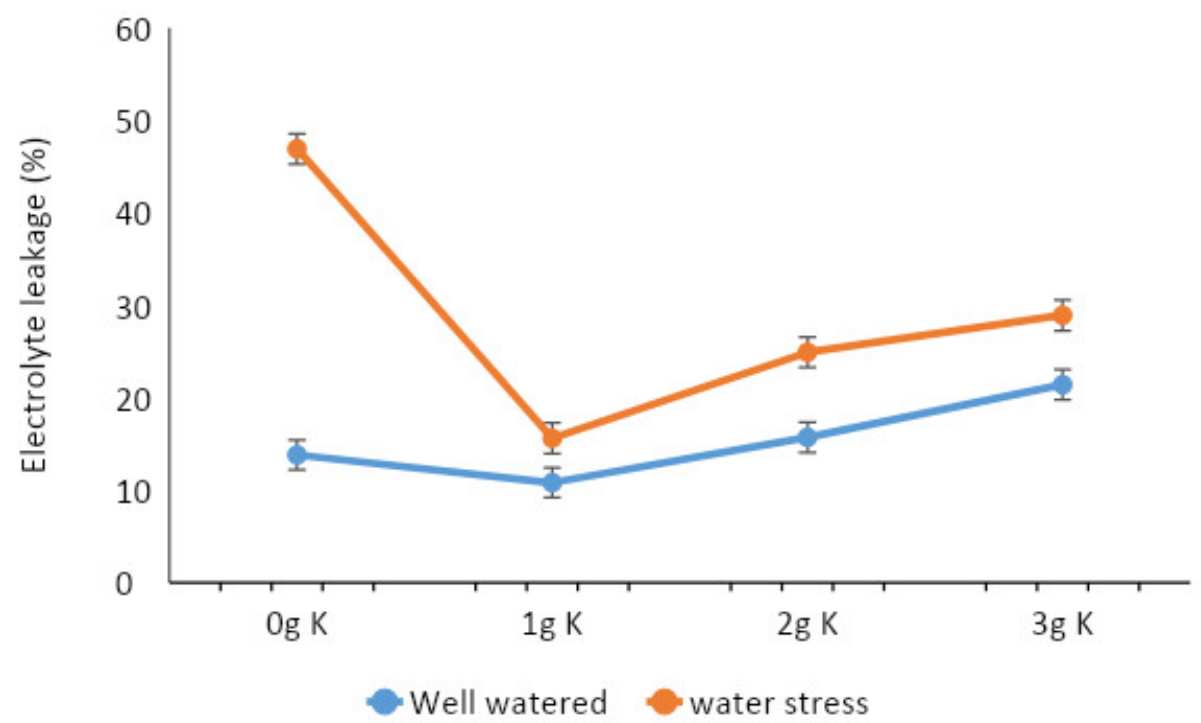

Figure 8. Effect of potassium on leaf electrolyte leakage of cocoa seedlings subjected to 35 days of water stress or well-watered conditions in a gauzehouse facility.

Varietal effects were significant for all physiological traits measured in both experiments. T63/967 $\times$ SCA 9 had the highest content of leaf chlorophyll under both wellwatered and water stress conditions, whereas varieties with PA 7 parentage showed significantly lower contents of chlorophyll under water stress (Table 6). Chlorophyll fluorescence was significantly lower in T63/967 $\times$ SCA 9 and PA $7 \times$ MAN 15-2 under well-watered 
conditions. Under water stress, the two varieties with SCA 9 parentage recorded a higher percentage reduction in leaf chlorophyll fluorescence, compared with those of PA 7 parentage. Leaf RWC and proportion of dry matter partitioned to roots were significant among varieties only under water stress conditions, with RWC being highest in T63/967 × SCA 9 and least in T85/799 $\times$ PA 7. A significant correlation was observed between the RWC and the proportion of dry matter partitioned to roots (Figure 9).

Table 6. Effects of watering regime and potassium levels on some physiological functions of four cocoa varieties in experiment 1 evaluated in a gauzehouse facility.

\begin{tabular}{|c|c|c|c|c|c|c|c|c|c|c|c|c|}
\hline \multirow[t]{2}{*}{ Varieties } & \multicolumn{2}{|c|}{$\begin{array}{l}\text { Leaf Chlorophyll } \\
\text { Content }\left(\mathrm{mmol} / \mathrm{cm}^{2}\right)\end{array}$} & \multicolumn{2}{|c|}{$\begin{array}{c}\text { Leaf Chlorophyll } \\
\text { Fluorescence (Fv/Fm) }\end{array}$} & \multicolumn{2}{|c|}{$\begin{array}{l}\text { Relative Water } \\
\text { Content }(\%)\end{array}$} & \multicolumn{2}{|c|}{$\begin{array}{c}\text { Electrolyte } \\
\text { Leakage (\%) }\end{array}$} & \multicolumn{2}{|c|}{$\begin{array}{l}\text { Leaf Phenol } \\
\text { Content (mg/g) }\end{array}$} & \multicolumn{2}{|c|}{$\begin{array}{l}\text { Leaf Proline } \\
\text { Content }(\mu \mathrm{g} / \mathrm{g})\end{array}$} \\
\hline & Watered & Stressed & Watered & Stressed & Watered & Stressed & Watered & Stressed & Watered & Stressed & Watered & Stressed \\
\hline T63/967 × SCA 9 & 12.8 & 5.6 & 0.61 & 0.16 & 75.4 & 13.0 & 9.9 & 36.1 & 11.6 & 20.2 & 13.4 & 996.2 \\
\hline T63/971 × SCA 9 & 10.0 & 4.7 & 0.67 & 0.17 & 73.2 & 9.3 & 7.6 & 36.4 & 12.2 & 23.9 & 5.9 & 2108.4 \\
\hline PA $7 \times$ MAN 15-2 & 10.0 & 4.2 & 0.61 & 0.26 & 72.0 & 9.6 & 9.0 & 27.0 & 10.4 & 15.7 & 9.7 & 1092.8 \\
\hline T85/799 $\times$ PA 7 & 8.4 & 4.1 & 0.66 & 0.33 & 72.6 & 7.7 & 8.7 & 16.7 & 10.6 & 16.8 & 20.1 & 1094.0 \\
\hline $\mathrm{SED}_{\mathrm{df}=32}$ & 0.87 & 0.72 & 0.02 & 0.07 & 2.67 & 0.88 & 0.55 & 1.65 & 0.11 & 0.22 & 0.71 & 9.92 \\
\hline
\end{tabular}

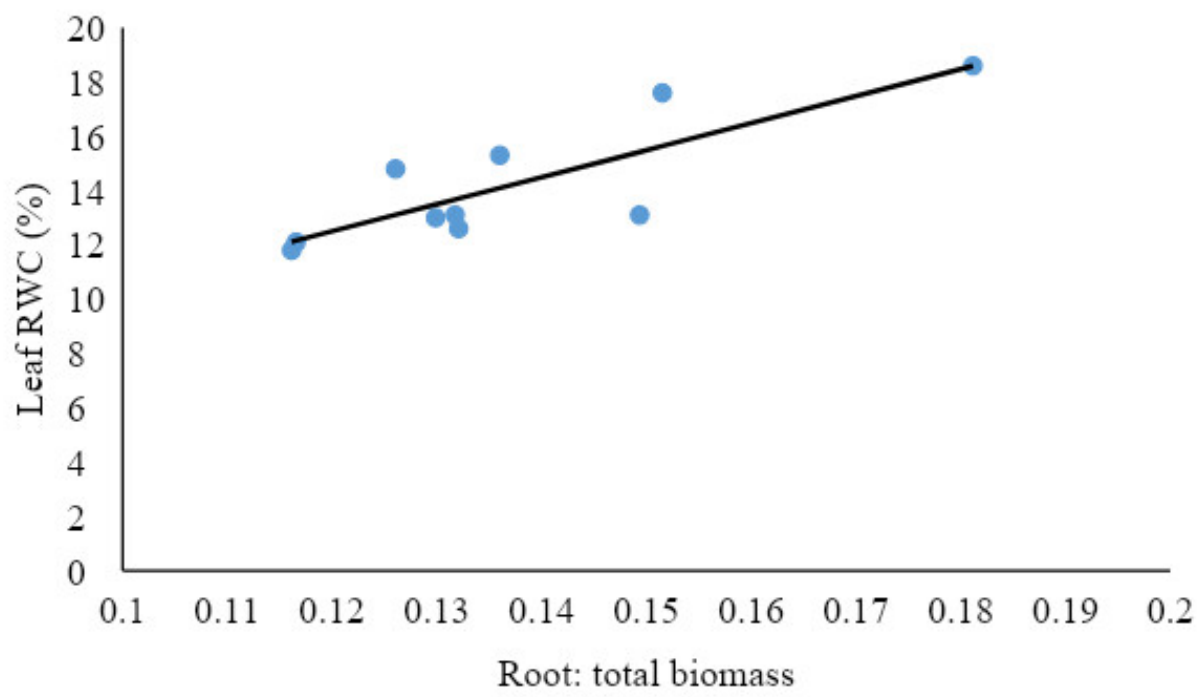

Figure 9. Relationship between leaf relative water content (RWC) and dry matter partitioned to roots of ten cocoa seedling varieties evaluated under 45 days of water stress in a gauzehouse facility.

Varieties showed significant differences for leaf membrane stability and phenol content, and varieties having SCA 9 parentage showed significantly higher electrolyte leakage and higher contents of leaf total phenols under water stress compared with those with PA 7 parentage. There was a significant variety $\times$ watering regime interaction for leaf proline content. T63/971 $\times$ SCA 9, which had the least content of leaf proline under well-watered conditions, was the variety with the highest content under water stress. The two varieties with PA 7 in their parentage expressed similar levels of leaf proline under water stress (Table 6).

\subsection{Effects of Variety and Potassium Application on Cocoa Seedling Survival under Water Stress}

Seedling mortality under water stress started six weeks after the last watering event, with no interaction between variety and $\mathrm{K}$ application. The number of deaths progressed across all treatments (K application rates and varieties) with increasing intensity of water stress (over time). After 6 days of withholding water, soil water content in stressed treatments was on average $70 \%$ of well-watered pots. This proportion reduced to $28 \%$, $21 \%$ and $16 \%$ by 14,20 , and 31 days after stress imposition, respectively. This steep imposition of water stress might be responsible for the lack of statistical significance 
$(p=0.23)$ observed for the effects of variety on seedling survival in the Kaplan-Meier survival curves. The log-rank tests indicated in Table 7 associated with the Kaplan-Meier survival curves (Figure 10a,b) show that $\mathrm{K}$ application was more important for seedling survival under drought than the effect of varieties (Figure 5a,b). Figure 10a depicts that the likelihood of survival was greater at $6,7,8$, and 9 weeks of water stress for seedlings that received $3 \mathrm{~g}$ MOP than any other level of applied $\mathrm{K}$. As shown in Table 7, compared with the control, the hazard ratio for death was $0.47(95 \% \mathrm{CI}=0.23-0.95)$ in favor of seedlings that received $3 \mathrm{~g}$ MOP. This indicates that seedlings in this group experienced mortality at a rate $53 \%$ slower than those in the control group. No other pairwise comparisons were significant as evidenced by the $95 \%$ confidence intervals associated with the hazard ratios. For the effect of variety on seedling survival over time, seedlings of T85/799 $\times$ PA 7 had the highest survival probabilities from $65 \%$ in the sixth week to $35 \%$ in the eighth week (Figure 10b). Compared with T85/799 $\times$ PA 7, the hazard ratios (with 95\% confidence intervals) were 0.71 (0.36 to 1.41) for PA $7 \times$ Man 15-2; 0.68 (0.34 to 1.33) for T63/967 $\times$ SCA 9 and $0.58(0.29$ to 1.15$)$ for T63/971 $\times$ SCA 9 . This indicates that seedlings of T85/799 $\times$ PA7 experience death from water stress at a rate $29 \%, 32 \%$ and $42 \%$ slower than seedlings of PA $7 \times$ Man 15-2, T63/967 $\times$ SCA 9 and T63/971 $\times$ SCA 9, respectively. As the upper bound confidence interval estimates were greater than 1.0, the statistical significance of the differences in the hazard ratios suggest a weak influence of varietal differences on seedling mortality.

Table 7. Hazard ratios from the Kaplan-Meier survival analyses for cocoa seedlings under soil water stress conditions as affected by variety and potassium application in experiment 1 .

\begin{tabular}{|c|c|c|c|c|c|c|c|c|c|}
\hline & \multicolumn{4}{|c|}{ Hazard Ratios for Varieties (95\% Confidence Intervals) } & \multicolumn{5}{|c|}{ Hazard Ratios for K Levels (95\% Confidence Intervals) } \\
\hline & PA $7 \times$ MAN 15-2 & T63/967 $\times$ SCA 9 & T63/971 $\times$ SCA 9 & T85/799 $\times$ PA 7 & & $0 \mathrm{~g} \mathrm{~K}$ & $1 \mathrm{~g} \mathrm{~K}$ & $2 \mathrm{~g} \mathrm{~K}$ & $3 \mathrm{~g} \mathrm{~K}$ \\
\hline PA $7 \times$ MAN 15-2 & - & $1.05(0.52-2.54)$ & $1.23(0.60-2.55)$ & $0.71(0.36-1.41)$ & $0 \mathrm{~g} \mathrm{~K}$ & - & $\begin{array}{c}0.79 \\
(0.38-1.64)\end{array}$ & $\begin{array}{c}0.87 \\
(0.41-1.83)\end{array}$ & $\begin{array}{c}0.47 \\
(0.23-0.95)\end{array}$ \\
\hline T63/967 × SCA 9 & & - & $1.17(0.58-2.40)$ & $0.68(0.34-1.33)$ & $1 \mathrm{~g} \mathrm{~K}$ & & 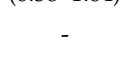 & $\begin{array}{c}1.10 \\
(0.54-2.22)\end{array}$ & $\begin{array}{c}0.59 \\
(0.31-1.15)\end{array}$ \\
\hline $\mathrm{T} 63 / 971 \times \mathrm{SCA} 9$ & & & - & $0.58(0.29-1.15)$ & $2 \mathrm{~g} \mathrm{~K}$ & & & - & $\begin{array}{c}0.54 \\
(0.27-1.07)\end{array}$ \\
\hline $\mathrm{T} 85 / 799 \times$ PA 7 & & & & - & $3 \mathrm{~g} \mathrm{~K}$ & & & & - \\
\hline Log-rank test & \multicolumn{4}{|c|}{$\chi_{\mathrm{df}=3}^{2}=4.31 ; p=0.23$} & \multicolumn{5}{|c|}{$\chi_{\mathrm{df}=3}^{2}=8.27 ; p=0.04$} \\
\hline
\end{tabular}
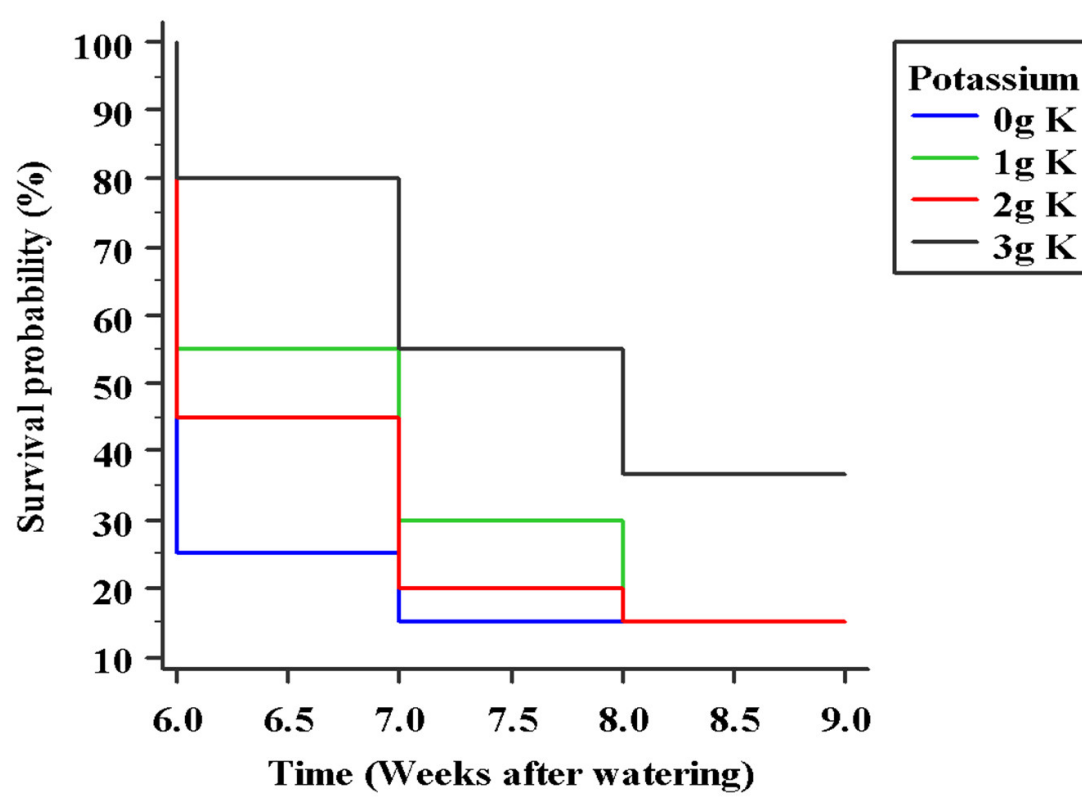

(a)

Figure 10. Cont. 

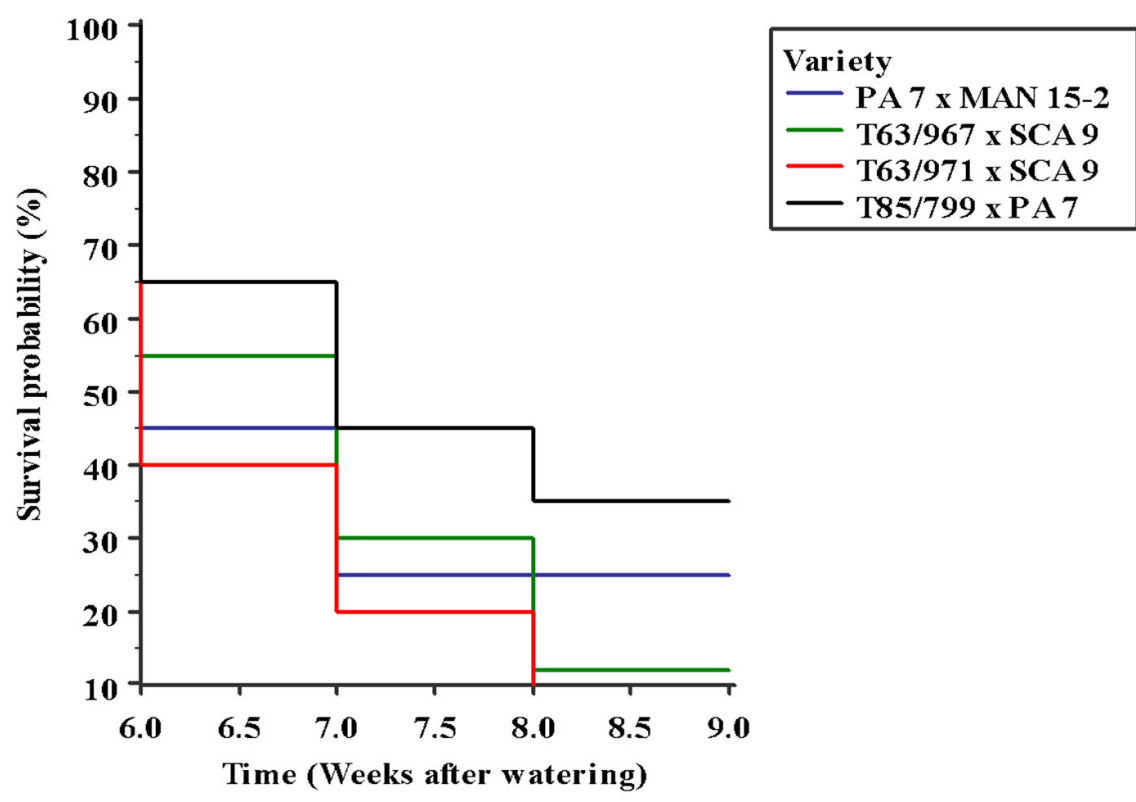

(b)

Figure 10. Survival curves of cocoa seedlings under water stress estimated using Kaplan-Meier's method (a) effect of potassium, log-rank test $p=0.040$; (b) effect of genotypes, log-rank test $p=0.2301$. $\mathrm{K}$ refers to Muriate of potash applied per plant.

\section{Discussion}

The results of the present study show that $\mathrm{K}$ application significantly influences the physiological responses of cocoa seedlings to better tolerate soil water stress. Leaf water status, chlorophyll function and leaf membrane integrity were all improved under soil water stress conditions, leading to significantly better survival of cocoa seedlings that received $\mathrm{K}$ under moisture stress. Our results suggest that increasing levels of applied $\mathrm{K}$ tend to increase overall biomass production (root and shoot) and the proportion of dry matter partitioned to roots. Consistent with earlier studies, Gattward et al., [37] observed that at low soil $\mathrm{K}$ levels, leaf stomatal conductance, and transpiration rates in field-grown cocoa seedlings were decreased, which led to reduced carbon dioxide assimilation and biomass accumulation. Orchard [38] showed that young cacao plants reacted to high $\mathrm{K}$ supply by increasing leaf area and that there was a reduced transpiration rate with increasing application of $\mathrm{K}$. These roles of $\mathrm{K}$ have been attributed to stomatal regulation and corresponding higher rates of photosynthesis [39], and better translocation of photoassimilates for root growth [40]. Soils in the cocoa belt of West Africa are considered to have adequate $\mathrm{K}$ reserves [41,42], with a lower limit of adequacy of $\mathrm{K}$ for nutrition estimated at $0.25 \mathrm{cmol} / \mathrm{kg}$ [43]. In concurrence with these observations, in the present study, K application to well-watered seedlings compromised physiological functions of cocoa seedlings in terms of chlorophyll content and fluorescence, and increased electrolyte leakage, suggesting excessive soil K concentration at optimal soil water contents.

Under water stress conditions, both contents of soil available $\mathrm{P}$ and $\mathrm{K}$ at the end of the experiment were higher than under well-watered conditions. Interestingly, where $\mathrm{K}$ was not applied, the content of soil-exchangeable $\mathrm{K}$ was similar for both water-stressed and well-watered treatments. Reduction in the uptake of $\mathrm{K}$ and $\mathrm{P}$ under drought has been observed in several other studies [44,45]. Reduced K uptake under moisture stress has been attributed to reduction in root hydraulic conductance that reduces $\mathrm{K}$ ion transport in the plant [46], and to the reduced mobility of $\mathrm{K}$ ions in the soil [47]. It is also probable that root morphological changes evidenced by the reduction in length of tap root and reduced root biomass under drought also contributed to reduced uptake of these nutrients in the soil and the observed higher contents in the soils in the present study. The lack of significant 
difference between varieties on soil contents of $\mathrm{K}$ and $\mathrm{P}$ at the end of the experiments points to a stronger effect of poor mobility of soil nutrients under water stress than to variety effects due to root morphology adjustments.

Cocoa variety response to soil water stress in terms of allometry, soil water extraction, chlorophyll function and synthesis of secondary metabolites was associated with their genotypic pedigrees. Under field conditions in Ghana, Padi et al., [11] demonstrated significant variety differences in seedling survival to moisture stress, accounted for by differences in the increase in stem diameter. Similarly, dos Santos et al., [3] observed that total dry matter accumulation was an important parameter that distinguished drought tolerance from sensitive varieties in greenhouse tests using six-month-old seedlings. The effects of drought on biomass accumulation have previously been shown to be due to the reduction in photosynthesis and Fv/Fm in cocoa cultivars under drought [48]. In our current analyses, water stress impacted root biomass more than shoot biomass. The observed positive correlation between varieties with a higher root:total biomass ratio and higher RWC under water stress is probably more the result of reduced water loss in above plant parts under water stress than due to better water uptake from root proliferation in these varieties. Variation in the capacity of cocoa varieties to conserve water by rapid closure of stomata in response to soil water deficits has been demonstrated by de Almeida [49]. Evidenced by the higher soil water content under varieties with PA 7 parentage (under both well-watered and water-stressed conditions) and higher root biomass under water stress, there is scope for selecting cocoa varieties with reduced water requirements for survival in drought-prone environments.

Leaf senescence is a hallmark of cocoa seedling response to water stress. Leaf senescence is marked by decline in chlorophyll and protein levels, a decrease in photochemical efficiency and membrane ion leakage [50]. Reductions in $\mathrm{Fv} / \mathrm{Fm}$ (which is a stable measure of the maximal quantum yield of photosystem II, [51,52]) and electrolyte leakage ([53,54] have been put forward as accurate indicators of tolerance to soil water stress. Varieties with PA 7 parentage that recorded reduced seedling mortalities with increasing intensity of soil water stress had higher indices of both $\mathrm{Fv} / \mathrm{Fm}$ and leaf membrane stability (electrolyte leakage).

Several experiments have indicated that plants exposed to drought stress produce higher concentration of phenolic compounds [55,56], and a large number of amino acids including proline [57]. Elevated amounts of these secondary metabolites have been considered as a strategy of higher plants to tolerate drought $[58,59]$ due to the antioxidant activity of phenols to control excessive ROS formation in tissues [60,61], and the osmolyte function of proline in conserving tissue water [62]. The results of the present study do not support a direct relationship between the accumulation of these secondary metabolites with seedling survival under stress. Though both phenol and proline contents increased significantly under water stress, K application similarly increased the leaf contents of these compounds even under adequate soil moisture conditions. As concluded by Sulpice [63], accumulation of these metabolites might be more an indicator of drought stress than a mechanism to mitigate stress.

Soil water stress conditions used in the present study were particularly severe as evidenced by the sharp decline in soil water content in stressed treatments compared to well-watered pots after withholding water for six days. It has been shown that physiological responses of cocoa seedlings are affected when the soil water content is below $60-70 \%$ of the maximum available soil water capacity [64]. In the present experiment, soil moisture in the water-stressed treatments was on average $70 \%$ of the well-watered treatments by the sixth day of stress, reducing to about $20 \%$ by the fourteenth day. Seedling mortalities were recorded from the sixth week after cessation of watering. Though there was a lack of statistical significance from the effect of variety on cocoa seedling survival under moisture stress, PA7-derived varieties had better seedling survival. The probable mechanism accounting for differences among cocoa varieties appear to be proportion of biomass partitioned to above-ground parts for varieties with PA 7 parentage, which led to differences in total area 
for water loss (or better stomatal closure under water stress), resulting in reduced water uptake from the soil for PA 7-derived varieties compared with other types. The resulting higher soil water content under these varieties (PA 7 derived) favored reduced electrolyte leakage from the leaf membrane and better chlorophyll fluorescence. These, in concert, led to delayed death of seedlings in PA 7 derived varieties compared, in particular, with SCA 9-derived varieties.

In summary, the beneficial effects of $\mathrm{K}$ on improving cocoa seedling growth may be limited only to conditions of water stress, as the reservoir of $\mathrm{K}$ in soils under cocoa appears adequate for growth under well-watered conditions. Validation of the results of the present study under field conditions is particularly recommended to apply the findings to improve cocoa seedling survival in drought-prone areas. If the results of the present study conducted under gauzehouse conditions hold true under field conditions, high $\mathrm{K}$ application to cocoa varieties with PA 7 parentage will lead to better seedling survival under drought conditions during the seedling stage.

\section{Conclusions}

Across West Africa, current recommendation on fertilization of cocoa in the seedling stage typically focuses on application of liberal amounts of nitrogen for rapid vegetative growth. The present results are informative in the light of increasing dry spells in the major cocoa regions, regarding drought mitigation strategies for cocoa. First, it is evident that regardless of variety used, $\mathrm{K}$ application improved cocoa seedling tolerance to water stress, with increasing $\mathrm{K}$ levels associated with increased tissue water retention, growth and survival. Under the experimental conditions used, application of potassium up to $3 \mathrm{~g} \mathrm{~K}$ (applied as muriate of potash) was beneficial for tolerance to water stress. Second, significant genetic differences exist in cocoa for responses to water stress during the seedling stage. By increasing the germplasm base and diversity in future tests, it is probable that varieties more tolerant to water stress than the best variety observed in the present study $($ T85/799 $\times$ PA 7) may be obtained. There is scope therefore for increasing cocoa seedling tolerance to water stress by a combination of suitably selected varieties and appropriate K levels.

Author Contributions: Conceptualization, E.A.; methodology, E.A., S.T.L., J.A.D. and F.K.P.; software, E.A. and F.K.P.; validation, E.A. and F.K.P.; formal analysis, E.A. and F.K.P.; investigation, E.A., S.T.L., J.A.D. and F.K.P.; data curation, E.A.; writing-original draft, E.A.; writing-review \& editing, E.A., S.T.L., J.A.D. and F.K.P.; visualization, E.A. and F.K.P.; supervision, E.A., S.T.L., J.A.D. and F.K.P.; project administration, E.A.; funding acquisition, E.A. All authors have read and agreed to the published version of the manuscript.

Funding: This research was funded by the Ghana Cocoa Board (CRIG/CC/03/04).

Institutional Review Board Statement: Not applicable.

Informed Consent Statement: Not applicable.

Data Availability Statement: In addition to data reported in this article, further supporting data are available on request from the corresponding author.

Acknowledgments: We appreciate the help of the technical staff at the Physiology/Biochemistry and Soil Science Divisions of Cocoa Research Institute of Ghana (CRIG). The article is published with the kind permission of the Executive Director, CRIG as manuscript number CRIG/02/2020/055/001.

Conflicts of Interest: The authors declare no conflict of interest.

\section{References}

1. Anim-Kwapong, G.J.; Frimpong, E.B. Vulnerability of Agriculture to Climate Change-Impact of Climate Change on Cocoa. 2005. Available online: https: / / citeseerx.ist.psu.edu/viewdoc / download?doi=10.1.1.494.4508\&rep=rep1\&type=pdf $($ accessed on 1 May 2017).

2. Läderach, P.; Martinez, A.; Schroth, G.; Castro, N. Predicting the future climatic suit-ability for cocoa farming of the world's leading producer countries, Ghana and Côte d'Ivoire. Clim. Chang. 2013, 119, 841-854. [CrossRef] 
3. Dos Santos, I.C.; De Almeida, A.-A.F.; Anhert, D.; Da Conceição, A.S.; Pirovani, C.P.; Pires, J.L.; Valle, R.R.; Baligar, V.C. Molecular, Physiological and Biochemical Responses of Theobroma cacao L. Genotypes to Soil Water Deficit. PLoS ONE 2014, 9, e115746. [CrossRef]

4. Ruf, F.; Schroth, G.; Doffangui, K. Climate change, cocoa migrations and deforestation in West Africa: What does the past tell us about the future? Sustain. Sci. 2015, 10, 101-111. [CrossRef]

5. Carr, M.K.V.; Lockwood, G. The water relations and irrigation requirements of cocoa (Theobroma cacao L.): A review. Exp. Agric. 2011, 47, 653-676. [CrossRef]

6. Schroth, G.; Läderach, P.; Martinez-Valle, A.I.; Bunn, C.; Jassogne, L. Vulnerability to climate change of cocoa in West Africa: Patterns, opportunities and limits to adaptation. Sci. Total. Environ. 2016, 556, 231-241. [CrossRef] [PubMed]

7. Guo, L.B.; Gifford, R.M. Soil carbon stocks and land use change: A meta analysis. Glob. Chang. Biol. 2002, 8, 345-360. [CrossRef]

8. Anim-Kwapong, G.J.; Frimpong, E.B. Vulnerability of agriculture to climate change- impact of climate change on cocoa production. In Report on Vulnerability and Adaptation Assessment under The Netherlands Climate Change Studies Assistance Programme Phase 2 (NCCSAP2); Cocoa Research Institute of Ghana: New Tafo-Akim, Ghana, 2006; p. 44.

9. Oppong, F.; Opoku-Ameyaw, K.; Osei-Bonsu, K.; Amoah, F.; Brew, K.; Acheampong, K. The effect of time of planting at stake on cocoa seedling survival. Ghana J. Agric. Sci. 1999, 32, 79-86. [CrossRef]

10. Oppong, F.; Osei-Bonsu, K.; Amoah, F.; Acheampong, K. Potential use of Flemingia macrophylla as mulch for managing weeds in young cocoa in Ghana. Ghana J. Agric. Sci. 1998, 31, 67-72. [CrossRef]

11. Padi, F.K.; Adu-Gyamfi, P.; Akpertey, A.; Arthur, A.; Ofori, A. Differential response of cocoa families to field establishment stress. Plant Breed. 2013, 132, 229-236. [CrossRef]

12. Ofori, A.; Padi, F.K.; Acheampong, K.; Lowor, S. Genetic variation and relationship of traits related to drought tolerance in cocoa (Theobroma cacao L.) under shade and no-shade conditions in Ghana. Euphytica 2014, 201, 411-421. [CrossRef]

13. Asare, R.; Ræbild, A. Tree diversity and canopy cover in cocoa systems in Ghana. New For. 2016, 47, $287-302$.

14. Cakmak, I. The role of potassium in alleviating detrimental effects of abiotic stresses in plants. J. Plant Nutr. Soil Sci. 2005, 168, 521-530. [CrossRef]

15. Rodriguez, D.; Andrade, F.; Goudriaan, J. Effects of phosphorus nutrition on tiller emergence in wheat. Plant Soil 1999, 209, 283-295. [CrossRef]

16. Jensen, P. Effects of interrupted $\mathrm{K}^{+}$supply on growth and uptake of $\mathrm{K}^{+}, \mathrm{Ca}^{2+}, \mathrm{Mg}^{2+}$ and $\mathrm{Na}^{+}$in spring wheat. Physiol. Plant. 1982, 56, 259-265. [CrossRef]

17. Elumalai, R.P.; Nagpal, P.; Reed, J.W. A Mutation in the Arabidopsis KT2/KUP2 Potassium Transporter Gene Affects Shoot Cell Expansion. Plant Cell 2002, 14, 119-131. [CrossRef]

18. Wang, M.; Zheng, Q.; Shen, Q.; Guo, S. The Critical Role of Potassium in Plant Stress Response. Int. J. Mol. Sci. 2013, 14, 7370-7390. [CrossRef] [PubMed]

19. Egilla, J.N.; Davies, F.T.; Boutton, T.W. Drought stress influences leaf water content, photosynthesis, and water-use efficiency of Hibiscus rosa-sinensis at three potassium concentrations. Photosynthetica 2005, 43, 135-140. [CrossRef]

20. Mengel, K.; Kirkby, E.A. Principles of Plant Nutrition; Kluwer Academic Publishers: Dordrecht, The Netherlands, 2001.

21. De la Guardia, M.D.; Benlloch, M. Effects of potassium and gibberellic acid on stem growth of whole sunflower plants. Physiol. Plant. 1980, 49, 443-448. [CrossRef]

22. Blanchet, R.; Studer, R.; Chaumont, C. Quelques aspects des interactions entre l'alimentation potassique et l'alimentation hydrique des plantes. Ann. Agron. 1962, 13, 93.

23. Benlloch-Gonzalez, M.; Arquero, O.; Fournier, J.M.; Barranco, D.; Benlloch, M. $\mathrm{K}^{+}$starvation inhibits water-stress-induced stomatal closure. J. Plant Physiol. 2008, 165, 623-630. [CrossRef] [PubMed]

24. Lockwood, G.; Gyamfi, M.M.O. The CRIG Cocoa Germplasm Collection with Notes on Codes Used in the Breeding Programme at Tafo and Elsewhere; Technical Bulletin, No. 10; Cocoa Research Institute of Ghana: Tafo, Ghana, 1979; p. 62.

25. Padi, F.K.; Ofori, A.; Takrama, J.; Djan, E.; Opoku, S.Y.; Dadzie, A.M.; Bhattacharjee, R.; Motamayor, J.C.; Zhang, D. The impact of SNP fingerprinting and parentage analysis on the effectiveness of variety recommendations in cacao. Tree Genet. Genomes 2015, 11, 44. [CrossRef]

26. Eskes, A.B. Collaborative and participatory approaches to cocoa variety improvement. In Final Report of the CFC/ICCO/Bioversity Project on Cocoa Productivity and Quality Improvement: A Participatory Approach (2004-2010); CFC: Amsterdam, The Netherlands; ICCO: London, UK; Bioversity International: Rome, Italy, 2011; p. 205.

27. Walkley, A.; Black, I.A. An examination of the Degtjareff method for determining organic carbon in soils: Effect of variations in digestion conditions and of inorganic soil constituents. Soil Sci. 1934, 63, 251-263. [CrossRef]

28. Van Reeuwijk, L.P. Procedures for Soil Analysis, 3rd ed.; Technical Paper 9; International Soil Reference and Information Centre: Wageningen, The Netherlands, 1992.

29. Bremner, J.M.; Mulvaney, C.S. Nitrogen-Total. In Methods of Soil Analysis. Part 2, 2nd ed.; Agronomy Monograph. 9; Page, A.L., Miller, R.H., Eds.; ASA: Madison, WI, USA; SSSA: Madison, WI, USA, 1982; pp. 595-624.

30. Truog, E. The Determination of the Readily Available Phosphorus of Soils 1. Agron. J. 1930, 22, 874-882. [CrossRef]

31. Thomas, G.W. Exchangeable cations. In Methods of Soil Analysis, Part 2; Chemical and Microbiological Properties; Page, A.L., Miller, R.H., Keeney, D.R., Eds.; Soil Science Society of America, Madison Wisconsin USA: Madison, WL, USA, 1982. 
32. Yamasaki, S.; Dillenburg, L.R. Measurements of leaf relative water Content in Araucaria angustifolia. Rev. Bras. Fisiol. Veg. 1999, 11, 69-75.

33. Ragazzi, E.; Veronese, G. Quantitative analysis of phenolic compounds after thin-layer chromatographic separation. J. Chromatogr. A 1973, 77, 369-375. [CrossRef]

34. Bates, L.S.; Waldren, R.P.; Teare, I.D. Rapid determination of free proline for water-stress studies. Plant Soil 1973, 39, $205-207$. [CrossRef]

35. Lutts, S.; Kinet, J.M.; Bouharmont, J. NaCl-induced senescence in leaves of rice (Oryza sativa L.) cultivars differing in salinity resistance. Ann. Bot. 1996, 78, 389-398. [CrossRef]

36. Kaplan, E.L.; Meier, P. Nonparametric estimation from incomplete observations. J. Am. Stat. Assoc. 1958, 53, 457-481. [CrossRef]

37. Gattward, J.N.; Almeida, A.-A.F.; Souza, J.O.; Gomes, F.P.; Kronzucker, H.J. Sodium-potassium synergism in Theobroma cacao: Stimulation of photosynthesis, water-use efficiency and mineral nutrition. Physiol. Plant. 2012, 146, 350-362. [CrossRef]

38. Orchard, J.E. Effect of K on transpiration, leaf diffusive resistance and growth in seedlings of Theobroma cacao L. In Technical Report; Cepec/Ceplac: Ilhéus, Brazil, 1978; pp. 61-64.

39. Marschner, P. Marschner's Mineral Nutrition of Higher Plants, 3rd ed.; Academic Press: London, UK, 2012; pp. 178-189.

40. Romheld, V.; Kirkby, E.A. Research on potassium in agriculture: Needs and prospects. Plant Soil 2010, 335, 155-180. [CrossRef]

41. Ahenkorah, Y.; Akrofi, G.S. Amazon cacao (Theobroma cacao L.) shade and manurial experiment (K2- 01) at the Cocoa Research Institute of Ghana. I. First five years. Agron. J. 1968, 60, 591-594. [CrossRef]

42. Wessel, M. Fertilizer requirements of cacao (Theobroma cacao L.) in South-Western Nigeria. In Communication 61; Koninklijk Instituut voor de Tropen: Amsterdam, The Netherlands, 1971; p. 104.

43. Ahenkorah, Y.; Halm, B.J.; Appiah, M.R.; Akrofi, G.S. Fertilizer use on cacao rehabilitation projects in Ghana. In Proceeding of the 8th International Cocoa Research Conference, Cartagena, Colombia, 18-23 October 1981; pp. 165-170.

44. Kemp, W.P.; Moody, U.L. Relationships between Regional Soils and Foliage Characteristics and Western Spruce Budworm (Lepidoptera: Tortricidae) Outbreak Frequency. Environ. Entomol. 1984, 13, 1291-1297. [CrossRef]

45. Díaz, E.; Roldan, A. Effects of reforestation techniques on the nutrient content, photosynthetic rate and stomatal conductance of Pinus halepensis seedlings under semiarid conditions. Land Degrad. Dev. 2000, 11, 475-486. [CrossRef]

46. Steudle, E. Water uptake by roots: Effects of water deficit. J. Exp. Bot. 2000, 51, 1531-1542. [CrossRef]

47. Qi, J.; Sun, S.; Yang, L.; Li, M.; Ma, F.; Zou, Y. Potassium Uptake and Transport in Apple Roots Under Drought Stress. Hortic. Plant J. 2019, 5, 10-16. [CrossRef]

48. Ávila-Lovera, E.; Coronel, I.; Jaimez, R.E.; Urich, R.; Pereyra, G.; Araque, O.; Chacón, I.; Tezara, W. Ecophysiological traits of adult trees of Criollo cocoa cultivars (Theobroma cacao L.) from a germplasm bank in Venezuela. Exp. Agric. 2015, 52, 137-153. [CrossRef]

49. De Almeida, A.A.F. Some water relations aspects of Theobroma cocoa clones. In Proceedings of the 13th International Cocoa Research Conference, Kota Kinabalu, Malaysia, 8-14 October 2000; pp. 349-363.

50. Rolny, N.; Costa, L.; Carrión, C.; Guiamet, J.J. Is the electrolyte leakage assay an unequivocal test of membrane deterioration during leaf senescence? Plant Physiol. Biochem. 2011, 49, 1220-1227. [CrossRef]

51. Percival, G.C.; Keary, I.P.; Al-Habsi, S. An assessment of the drought tolerance of Fraxinus genotypes for urban landscape plantings. Urban For. Urban Green. 2006, 5, 17-27. [CrossRef]

52. Banks, J.M. Chlorophyll fluorescence as a tool to identify drought stress in Acer genotypes. Environ. Exp. Bot. 2018, 155, 118-127. [CrossRef]

53. Lim, P.O.; Kim, H.J.; Gil Nam, H. Leaf Senescence. Annu. Rev. Plant Biol. 2007, 58, 115-136. [CrossRef]

54. Lee, B.-H.; Zhu, J.-K. Phenotypic Analysis of Arabidopsis Mutants: Electrolyte Leakage after Freezing Stress. Cold Spring Harb. Protoc. 2010, 2010, 4970. [CrossRef]

55. De Abreu, I.N.; Mazzafera, P. Effect of water and temperature stress on the con-tent of active constituents of Hypericum brasiliense Choisy. Plant Physiol. Biochem. 2005, 43, 241-248. [CrossRef]

56. Jaafar, H.Z.; Ibrahim, M.H.; Fakri, N.F.M. Impact of soil field water capacity on secondary metabolites, phenylalanine ammonialyase (PAL), malondialdehyde (MDA) and photosynthetic responses of Malaysian Kacip Fatimah (Labisia pumila Benth). Molecules 2012, 17, 7305-7322. [CrossRef]

57. Anjum, S.A.; Farooq, M.; Xie, X.-Y.; Liu, X.-J.; Ijaz, M.F. Antioxidant defense system and proline accumulation enables hot pepper to perform better under drought. Sci. Hortic. 2012, 140, 66-73. [CrossRef]

58. Westoby, M.; Falster, D.S.; Moles, A.T.; Vesk, P.A.; Wright, I.J. Plant ecological strategies: Some leading dimensions of variation between species. Annu. Rev. Ecol. Syst. 2002, 33, 125-159. [CrossRef]

59. Reddy, A.R.; Chaitanyaa, K.V.; Vivekanandan, M. Drought-induced responsesof photosynthesis and antioxidant metabolism in higher plants. J. Plant Physiol. 2004, 161, 1189-1202. [CrossRef]

60. Hatier, J.-H.B.; Gould, K.S. Foliar anthocyanins as modulators of stress signals. J. Theor. Biol. 2008, 253, 625-627. [CrossRef]

61. Agati, G.; Tattini, M. Multiple functional roles of flavonoids in photoprotection. New Phytol. 2010, 186, 786-793. [CrossRef] [PubMed]

62. Ashraf, M.; Foolad, M. Roles of glycine betaine and proline in improving plant abiotic stress resistance. Environ. Exp. Bot. 2007, 59, 206-216. [CrossRef]

63. Sulpice, R. Closing the yield gap: Can metabolomics be of help? J. Exp. Bot. 2019, 71, 461-464. [CrossRef] [PubMed]

64. Alvim, P.T. Las necesidades de agua del cacao. Turrialba 1960, 10, 6-16. 